April 2002 • NREL/TP-510-31949

\title{
Assessment of Natural Gas Splitting with a Concentrating Solar Reactor for Hydrogen Production
}

Pamela L. Spath

Wade A. Amos

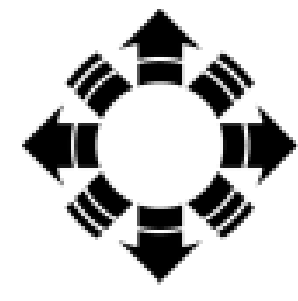

NPEI

National Renewable Energy Laboratory

1617 Cole Boulevard

Golden, Colorado 80401-3393

NREL is a U.S. Department of Energy Laboratory

Operated by Midwest Research Institute $\bullet$ Battelle $\bullet$ Bechtel

Contract No. DE-AC36-99-G010337 


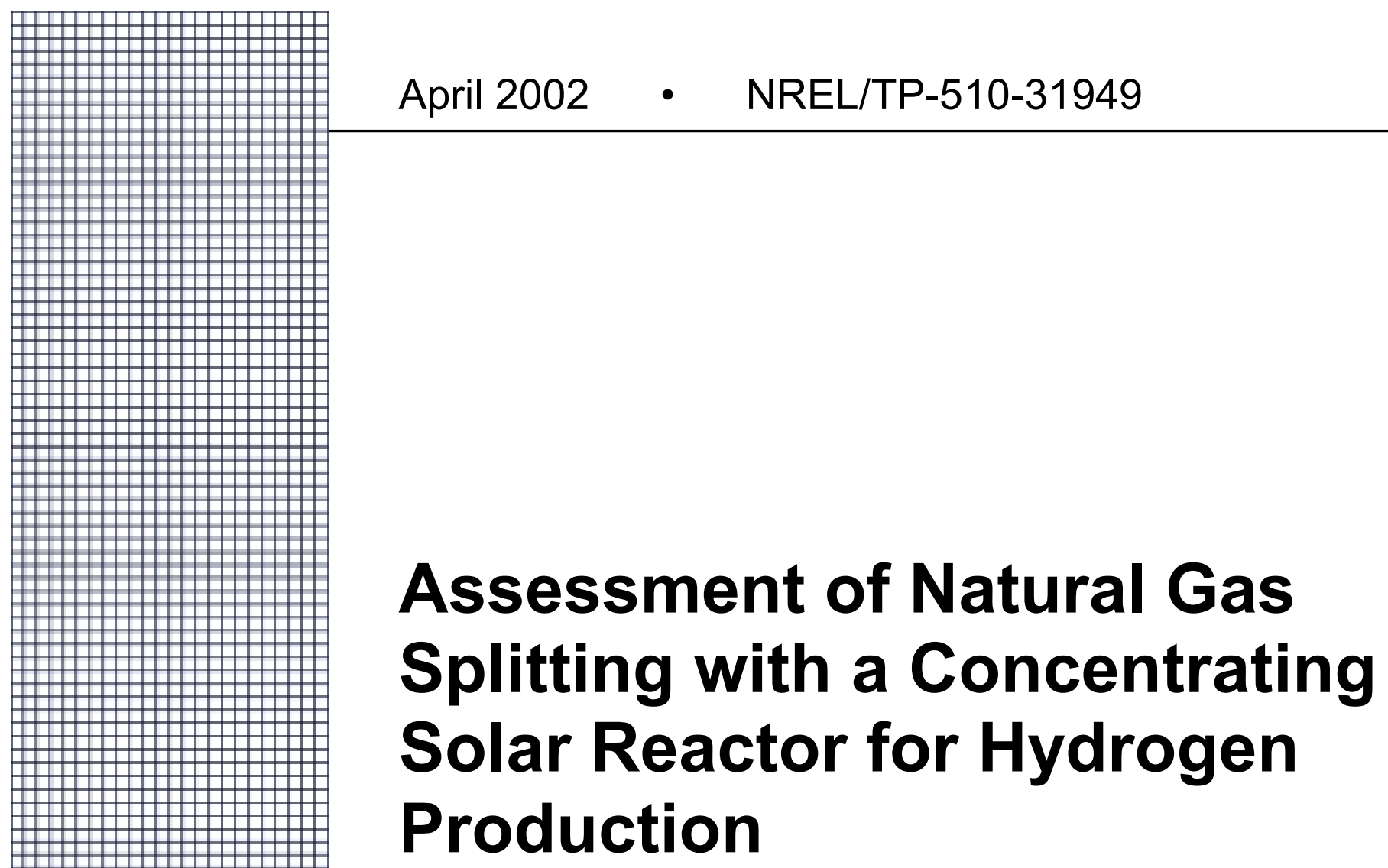

Pamela L. Spath

Wade A. Amos

Prepared under Task No. HY02.4041

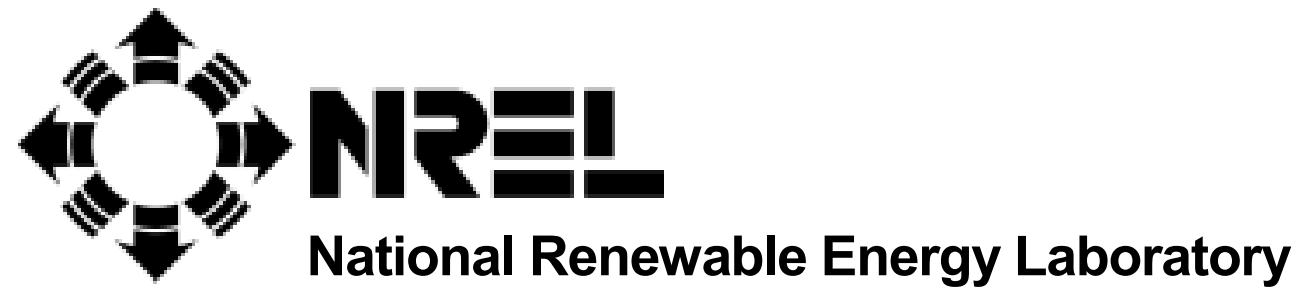

1617 Cole Boulevard

Golden, Colorado 80401-3393

NREL is a U.S. Department of Energy Laboratory

Operated by Midwest Research Institute $\bullet$ Battelle $\bullet$ Bechtel

Contract No. DE-AC36-99-G010337 


\section{NOTICE}

This report was prepared as an account of work sponsored by an agency of the United States government. Neither the United States government nor any agency thereof, nor any of their employees, makes any warranty, express or implied, or assumes any legal liability or responsibility for the accuracy, completeness, or usefulness of any information, apparatus, product, or process disclosed, or represents that its use would not infringe privately owned rights. Reference herein to any specific commercial product, process, or service by trade name, trademark, manufacturer, or otherwise does not necessarily constitute or imply its endorsement, recommendation, or favoring by the United States government or any agency thereof. The views and opinions of authors expressed herein do not necessarily state or reflect those of the United States government or any agency thereof.

Available electronically at http://www.osti.gov/bridge

Available for a processing fee to U.S. Department of Energy

and its contractors, in paper, from:

U.S. Department of Energy

Office of Scientific and Technical Information

P.O. Box 62

Oak Ridge, TN 37831-0062

phone: 865.576.8401

fax: 865.576 .5728

email: reports@adonis.osti.gov

Available for sale to the public, in paper, from:

U.S. Department of Commerce

National Technical Information Service

5285 Port Royal Road

Springfield, VA 22161

phone: 800.553 .6847

fax: 703.605.6900

email: orders@ntis.fedworld.gov

online ordering: http://www.ntis.gov/ordering.htm 


\section{Executive Summary}

Experimental analysis is being done for hydrogen production via thermal decomposition of methane using a solar reactor. The National Renewable Energy Laboratory (NREL) has analyzed this process for two different applications: (1) for a fueling station and (2) for power production. The fueling station application was examined as a stand-alone system. However, because storage limits the amount of hydrogen production and results in a substantial capital cost, the system was also examined as one that could supply hydrogen to a pipeline network. For the power production scenario, the hydrogen is co-fired in a turbine at a natural gas combined-cycle (NGCC) plant.

Material balances were obtained from an entrained flow reactor model developed by the University of Colorado. Energy balances were determined using Aspen Plus ${ }^{\circledR}$ and radiant heat loss calculations based on the size of the reactor. The material and energy balances along with hourly solar data from Phoenix, Arizona were used to determine how much hydrogen could be produced by the system. For a given reactor size, three hydrogen production rates were evaluated by varying the size of the heliostat field. First, the size of the heliostat field was set so that the reactor operating temperature at the highest hourly solar irradiance did not exceed $2,273 \mathrm{~K}$. This temperature was chosen as a practical limit. Next, the heliostat field was doubled, which meant that more hydrogen could be produced at lower light intensities, but at high light intensities, part of the heliostat field must be taken offline to avoid overheating the reactor. Finally, the size of the heliostat field was cut in half. This was done to reduce the capital costs. For the fueling station application, doubling the size of the heliostat field resulted in the lowest cost hydrogen. However, for the power production application the smallest heliostat field was the most economic option.

The following table gives the resulting hydrogen production and storage for the stand-alone fueling station application. For storage amounts of $800 \mathrm{~kg}, 1,400 \mathrm{~kg}$, and 2,300 kg for the three heliostat field areas, the daily demand that could be supplied by each refueling station is $250 \mathrm{~kg} / \mathrm{day}, 450 \mathrm{~kg} / \mathrm{day}$, and $750 \mathrm{~kg} /$ day of hydrogen, respectively. At $4 \mathrm{~kg} / \mathrm{car}$, this means that roughly 63,113 , and 188 cars are fueled each day for the different heliostat field sizes. There are many times when the storage capacity is reached and the hydrogen production system must be shutdown. For this reason, only $54 \%-66 \%$ of the total possible hydrogen production was actually produced. Increasing the size of the hydrogen storage did not significantly increase the amount of hydrogen that could be supplied for fuel. This small increase in useable hydrogen did not outweigh the large cost associated with storing the hydrogen.

Fueling Station - $\mathrm{H}_{2}$ Production, Storage, and Demand for Stand-Alone System

\begin{tabular}{|c|c|c|c|c|c|}
\hline $\begin{array}{c}\text { Heliostat } \\
\text { size }\left(\mathrm{m}^{2}\right)\end{array}$ & $\begin{array}{c}\mathrm{H}_{2} \text { produced } \\
\text { without storage } \\
\text { limit (tonne/yr) }\end{array}$ & $\begin{array}{c}\mathrm{H}_{2} \text { storage } \\
\text { capacity }(\mathrm{kg})\end{array}$ & $\begin{array}{c}\text { Daily } \mathrm{H}_{2} \\
\text { demand } \\
(\mathrm{kg} / \mathrm{day})\end{array}$ & $\begin{array}{c}\mathrm{H}_{2} \text { produced with } \\
\text { storage limit } \\
\text { (tonne/yr) }\end{array}$ & $\begin{array}{c}\text { \% produced (with } \\
\text { storage limit) of total } \\
\text { possible }\end{array}$ \\
\hline 2,188 & 169 & 800 & 250 & 91 & $54 \%$ \\
\hline 4,375 & 301 & 1,400 & 450 & 164 & $55 \%$ \\
\hline 8,750 & 416 & 2,300 & 750 & 273 & $66 \%$ \\
\hline
\end{tabular}

The carbon that is produced from the solar process is assumed to be sold in the carbon black market. The base case uses a carbon black price of $\$ 0.66 / \mathrm{kg}$, which is the price for carbon black in the tire industry. This is the largest market, accounting for $70 \%$ of the worldwide carbon black market. The following table gives the hydrogen selling price for the stand-alone fueling station application. 
Fueling Station $-\mathrm{H}_{2}$ Selling Price for Stand-Alone System (HHV basis)

\begin{tabular}{|c|c|c|c|}
\hline $\begin{array}{c}\text { Heliostat } \\
\text { size }\left(\mathrm{m}^{2}\right)\end{array}$ & \multicolumn{2}{|c|}{$\mathrm{H}_{2}$ selling price } & $\begin{array}{c}\text { Cost to fill fuel tank } \\
\text { with } 4 \mathrm{~kg} \mathrm{of} \mathrm{H}_{2}(\$)\end{array}$ \\
\cline { 2 - 3 } & $(\$ / \mathrm{GJ})$ & $(\$ / \mathrm{kg})$ & $\$ 49$ \\
\hline 2,188 & $\$ 87$ & $\$ 12$ & $\$ 42$ \\
\hline 4,375 & $\$ 73$ & $\$ 10$ & $\$ 32$ \\
\hline 8,750 & $\$ 57$ & $\$ 8$ & \multicolumn{2}{c}{} \\
\hline
\end{tabular}

Note: Fill up cost is without taxes.

Hydrogen storage was the largest capital cost item, accounting for $32 \%$ of the total capital for the 8,750 $\mathrm{m}^{2}$ heliostat field size. This was followed by the cost of the heliostat field $(21 \%)$ and hydrogen compression (19\%). However, it is important to remember that any competing system (renewable or nonrenewable) will also require some amount of storage as well as hydrogen compression for a stand-alone fueling station.

Because of the large costs for storage and compression, along with the fact that the storage limitation prevents maximum hydrogen production, this system was examined as one where the hydrogen could be sent directly to a pipeline network. For this scenario, the pipeline was assumed to already be in place, therefore, the expense of the pipeline was not included in the analysis. The following table shows the resulting economics for the largest heliostat size. The reduction in the hydrogen selling price is $68 \%$ from the stand-alone case. Note that this scenario is able to maximize hydrogen production, instead of utilizing only $54 \%-66 \%$ of the total possible hydrogen production like the stand-alone case.

\section{Fueling Station - $\mathrm{H}_{2}$ Selling Price when Supplied to Pipeline (HHV basis)}

\begin{tabular}{|c|c|c|c|}
\hline \multirow{2}{*}{$\begin{array}{c}\text { Heliostat } \\
\text { size }\left(\mathrm{m}^{2}\right)\end{array}$} & $\begin{array}{c}\mathrm{H}_{2} \text { produced from solar } \\
\text { process (tonne/yr) }\end{array}$ & \multicolumn{2}{|c|}{$\mathrm{H}_{2}$ selling price } \\
\cline { 3 - 4 } & $(\$ / \mathrm{GJ})$ & $(\$ / \mathrm{kg})$ \\
\hline 8,750 & 416 & $\$ 18$ & $\$ 3$ \\
\hline
\end{tabular}

One other option that was examined to help the productivity of the solar process was adding a small electric heater that can be turned on when the hydrogen supply gets low to provide heat to the solar reactor. Two scenarios using an electric heater were examined: one where the storage was kept constant and the daily demand was increased and one where the demand was kept constant and the hydrogen storage was decreased. For the constant storage case, if the daily demand is increased by $40 \%$ and only $5 \%$ of the hydrogen comes from the electric heater, then the amount of hydrogen produced from the sun increases from $66 \%$ to $88 \%$ of the total possible. More hydrogen comes from the sun because the backup equipment (i.e., the electric heater) supplies hydrogen during periods of clouds or inclement weather. For the constant demand case, using the electric heater to account for $5 \%$ of the hydrogen production decreased the storage requirements by a factor of 3 . See the table below for details. The hydrogen selling price with the supplemental electric heater is considerably less than the stand-alone base case at $\$ 42 / \mathrm{GJ}$ and $\$ 46 / \mathrm{GJ}$ for the constant storage and constant demand cases, respectively, compared to $\$ 57 / \mathrm{GJ}$.

Fueling Station - $\mathrm{H}_{2}$ Production, Storage, and Demand with Supplemental Electric Heater

\begin{tabular}{|c|c|c|c|c|c|c|c|c|}
\hline \multirow[t]{2}{*}{$\begin{array}{l}\text { Heliostat } \\
\text { size }\left(\mathrm{m}^{2}\right)\end{array}$} & \multirow{2}{*}{$\begin{array}{l}\mathrm{H}_{2} \text { produced } \\
\text { from solar } \\
\text { without } \\
\text { storage limit } \\
\text { (tonne/yr) }\end{array}$} & \multirow[t]{2}{*}{ Scenario } & \multirow{2}{*}{$\begin{array}{c}\mathrm{H}_{2} \\
\text { storage } \\
\text { capacity } \\
(\mathrm{kg})\end{array}$} & \multirow{2}{*}{$\begin{array}{l}\text { Daily } \mathrm{H}_{2} \\
\text { demand } \\
\text { (kg/day) }\end{array}$} & \multicolumn{2}{|c|}{$\begin{array}{c}\mathrm{H}_{2} \text { produced from solar } \\
\text { energy input }\end{array}$} & \multicolumn{2}{|c|}{$\begin{array}{c}\mathrm{H}_{2} \text { produced from } \\
\text { electric heater }\end{array}$} \\
\hline & & & & & (tonne/yr) & $\begin{array}{l}\% \text { of total } \\
\text { possible } \\
\text { from solar }\end{array}$ & (tonne/yr) & $\begin{array}{c}\% \text { of } \\
\text { total } \\
\text { produced }\end{array}$ \\
\hline \multirow[t]{3}{*}{8,750} & \multirow[t]{3}{*}{416} & $\begin{array}{l}\text { base } \\
\text { case }\end{array}$ & 2,300 & 750 & 273 & $66 \%$ & N/A & N/A \\
\hline & & $\begin{array}{l}\text { constant } \\
\text { storage }\end{array}$ & 2,300 & 1,050 & 365 & $88 \%$ & 17 & $4.5 \%$ \\
\hline & & $\begin{array}{l}\text { constant } \\
\text { demand }\end{array}$ & 750 & 750 & 260 & $62 \%$ & 14 & $5.2 \%$ \\
\hline
\end{tabular}


For the power production application, two options were examined: (1) selling the carbon black and (2) burning the carbon to produce more power. Because of its value, it is more profitable to sell the carbon instead of burning it. However, in order for the electricity produced from the hydrogen to be less than the base electricity production cost of the NGCC plant, the price of the carbon must be greater than $\$ 0.80 / \mathrm{kg}$. Even though the reactor and heliostat field sizes were increased compared to the fueling station application, the amount of power produced from the hydrogen is small compared to the size of the natural gas plant. For a $500 \mathrm{MW}$ NGCC plant, the electricity generated from the solar process only accounts for about $0.2 \%$ to $1.1 \%$ of the total output from the power plant. Therefore, even if the power produced from the hydrogen is more than the base power production price, overall, it would not significantly increase the price of electricity generation from the NGCC power plant and a small portion of the electricity from the power plant would be renewable. However, it should be noted that not all of the power from the hydrogen is renewable because the feedstock to the solar plant is natural gas. Only the heat input from the solar process is renewable. For the scenario where both the hydrogen and carbon are burned, only about $9 \%$ of the electricity produced from these feedstocks is renewable. This means that less than $0.1 \%$ of the total output from the power plant is renewable electricity.

The specialty markets for carbon black are smaller than the tire industry, but the price of the carbon in these markets is usually higher because of the more stringent carbon quality specifications. A sensitivity analysis was performed on several variables (carbon selling price, heliostat cost, price of natural gas, and greenhouse gas credit) but the price of the carbon black had the greatest effect on the economics. The following figure shows the sensitivity in the price of hydrogen for different carbon prices for the fueling station application. Higher value carbon markets should definitely be pursued and currently, tests are being performed to examine the compatibility of the carbon black produced from the solar reactor to the different grades and types of carbon black that are marketed today.

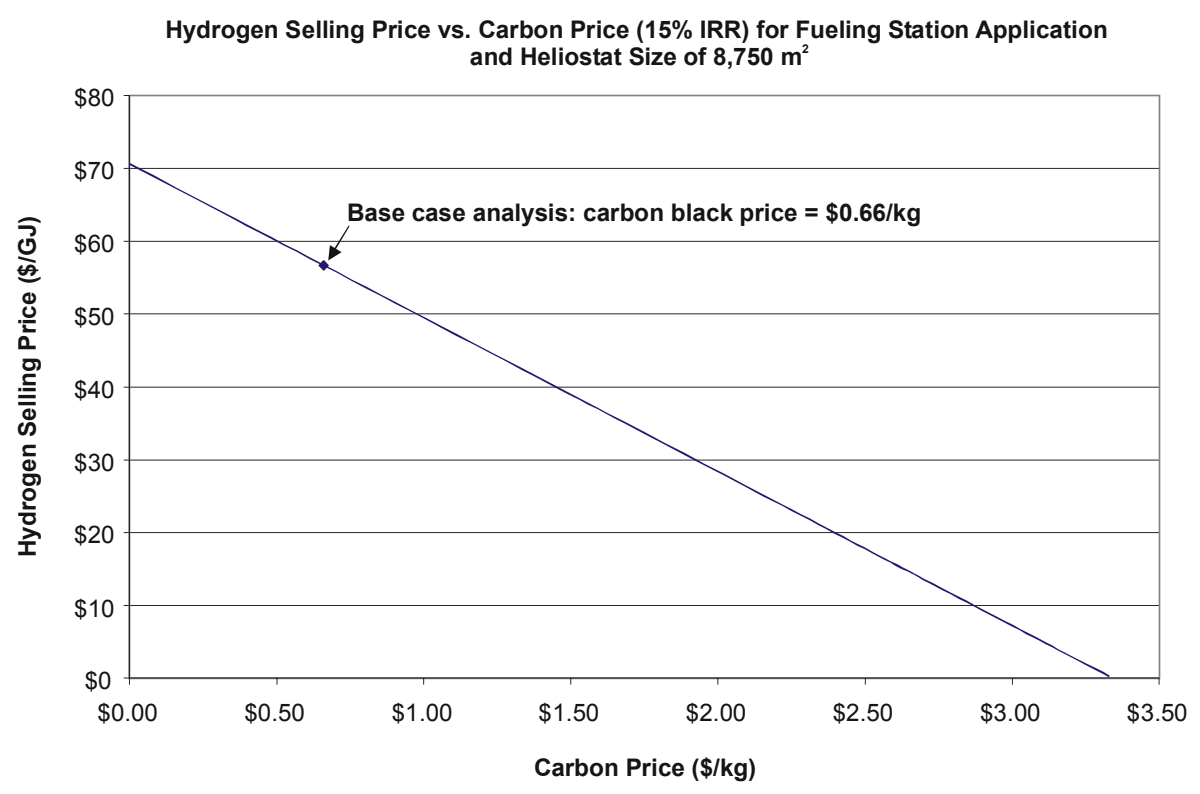

Although, the solar process for the fueling station and power production application use natural gas as a feedstock, the net greenhouse gas emissions and overall fossil energy consumption is lower for the solar process than for the conventional fossil system. It was evident that there is a significant environmental benefit from carbon black production via the solar route than from its conventional route. 


\section{Table of Contents}

Units of Measure

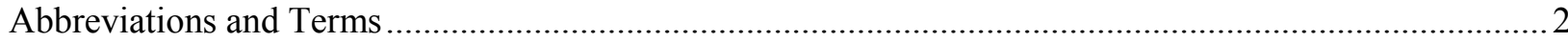

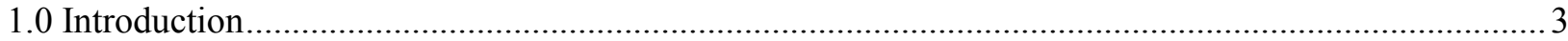

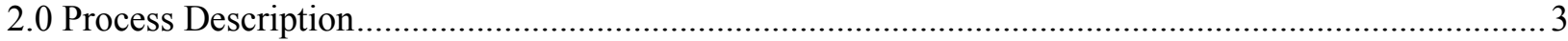

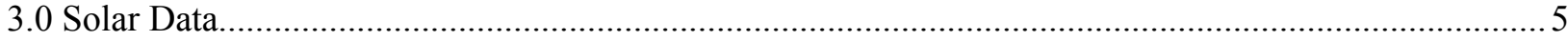

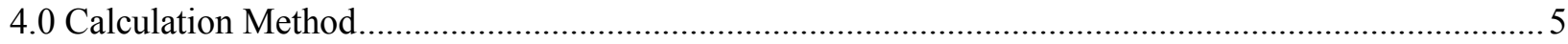

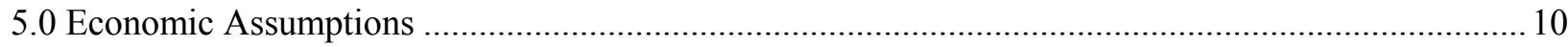

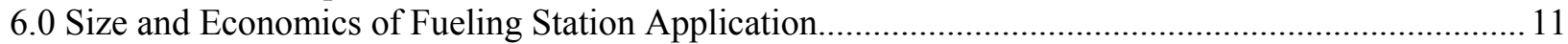

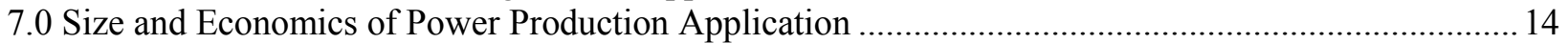

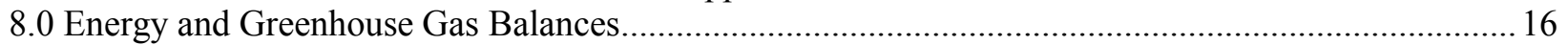

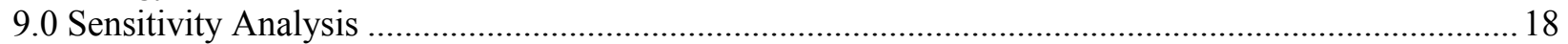

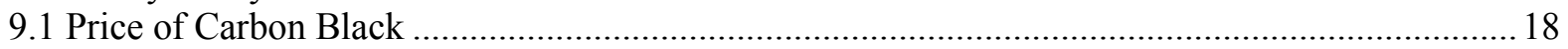

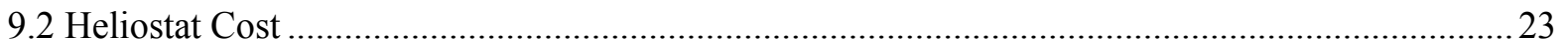

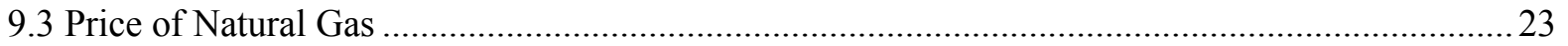

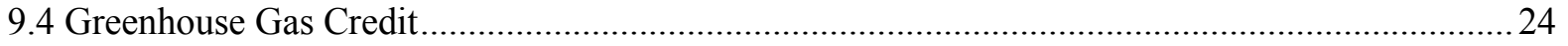

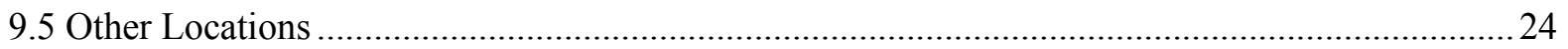

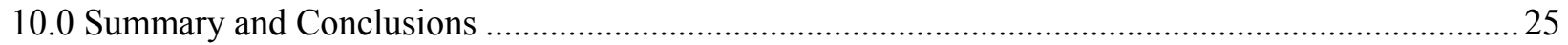

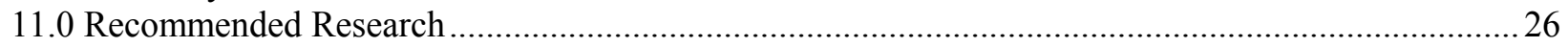

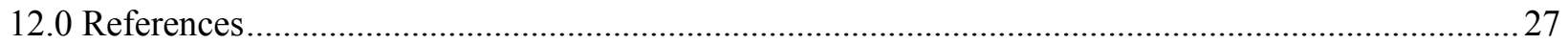




\section{List of Tables}

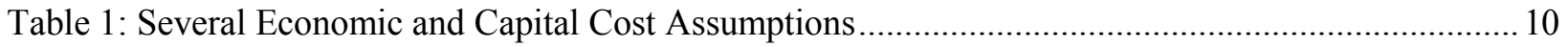

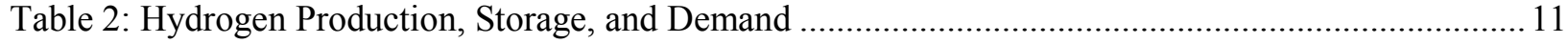

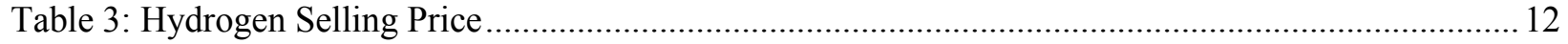

Table 4: Breakdown of Operating Costs and Revenue - Fueling Station Application ............................ 12

Table 5: Breakdown of Capital Costs - Fueling Station Application...................................................... 12

Table 6: Hydrogen Production, Storage, and Demand with Supplemental Electric Heater ..................... 13

Table 7: Hydrogen Selling Price with Supplemental Electric Heater for Heliostat Size of 8,750 m² ...... 14

Table 8: Hydrogen Selling Price when Supplied to Hydrogen Pipeline ................................................. 14

Table 9: $\mathrm{H}_{2}$, Carbon, and Electricity Produced for Power Production Application.................................. 15

Table 10: Breakdown of Operating Costs and Revenues - Power Application ....................................... 15

Table 11: Breakdown of Capital Costs - Power Application.................................................................. 15

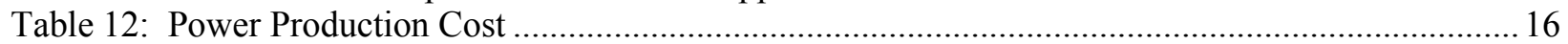

Table 13: Examining Market Share for Fueling Station Application ....................................................2

Table 14: Examining Market Share for Power Production Application .................................................2 21

Table 15: Fueling Station Application - Sensitivity to Heliostat Cost ....................................................23

Table 16: Power Production Application - Sensitivity to Heliostat Cost...............................................23

Table 17: Fueling Station Application - Sensitivity to the Price of Natural Gas .....................................2 24

Table 18: Power Production Application - Sensitivity to Price of Natural Gas......................................24

Table 19: Hydrogen Production, Storage, Demand, and $\mathrm{H}_{2}$ Selling Price - Los Angeles ........................25

Table 20: Hydrogen Production, Storage, Demand, and $\mathrm{H}_{2}$ Selling Price - Chicago ............................... 25

\section{List of Figures}

Figure 1: Process Flow Diagram for Fueling Station Application................................................... 4

Figure 2: Process Flow Diagram for Power Application ................................................................ 4

Figure 3: Hydrogen Production Rate versus Temperature for a Fixed Conversion.................................... 6

Figure 4: Methane Flow Rate vs. Reactor Wall Temperature to Achieve 70\% Conversion ...................... 8

Figure 5: Reactor Heat Duty vs. Reactor Wall Temperature to Achieve 70\% Conversion ........................ 8

Figure 6: Duty and Heat Loss versus Temperature to Achieve 70\% Conversion for a Heliostat Size of $8,750 \mathrm{~m}^{2}$

Figure 7: Hydrogen Production Rate versus Solar Irradiance to Achieve 70\% Conversion ......................... 9

Figure 8: Greenhouse Gas and Energy Balance - Fueling Station Application ...................................... 17

Figure 9: Greenhouse Gas and Energy Balance - Power Production Application.................................... 19

Figure 10: Hydrogen Selling Price vs. Carbon Price (15\% IRR) for Fueling Station Application and Heliostat Size of $8,750 \mathrm{~m}^{2}$

Figure 11: Additional Price to Base Electricity Coast vs. Carbon Price (15\% IRR) for the Power ..........22 


\section{Units of Measure}

Metric units of measure are used in this report. Therefore, material consumption is reported in units based on the gram (e.g., kilogram or megagram), energy consumption based on the joule (e.g., kilojoule or megajoule), and distance based on the meter (e.g., kilometer). When it can contribute to the understanding of the analysis, the English system equivalent is stated in parentheses. The metric units used for each parameter are given below, with the corresponding conversion to English units.

Mass: $\quad$ kilogram $(\mathrm{kg})=2.205$ pounds

megagram $(\mathrm{Mg})=$ metric tonne $(\mathrm{T})=1 \times 10^{6} \mathrm{~g}=1.102$ ton $(\mathrm{t})$

Distance: $\quad$ kilometer $(\mathrm{km})=0.62$ mile $=3,281$ feet

Area: $\quad$ hectare $($ ha $)=10,000 \mathrm{~m}^{2}=2.47$ acres

Volume: $\quad$ cubic meter $\left(\mathrm{m}^{3}\right)=264.17$ gallons normal cubic meters $\left(\mathrm{Nm}^{3}\right)=0.02628$ standard cubic feet (scf) at a standard temperature and pressure of $15.6^{\circ} \mathrm{C}\left(60^{\circ} \mathrm{F}\right)$ and $101.4 \mathrm{kPa}(14.7 \mathrm{psi})$, respectively

Pressure: $\quad$ megapascals $(\mathrm{MPa})=145$ pounds per square inch

Energy: $\quad$ kilojoule $(\mathrm{kJ})=1,000$ Joules $(\mathrm{J})=0.9488 \mathrm{Btu}$ gigajoule $(\mathrm{GJ})=0.9488 \mathrm{MMBtu}($ million $\mathrm{Btu})$ kilowatt-hour $(\mathrm{kWh})=3,414.7 \mathrm{Btu}$ gigawatt-hour $(\mathrm{GWh})=3.4 \times 10^{9} \mathrm{Btu}$

Power: $\quad$ megawatt $(\mathrm{MW})=1 \times 10^{6} \mathrm{~J} / \mathrm{s}$

Temperature: $\quad{ }^{\circ} \mathrm{C}=\left({ }^{\circ} \mathrm{F}-32\right) / 1.8$

\section{Hydrogen Equivalents:}

$1 \mathrm{~kg} \mathrm{H} 2=423.3 \mathrm{scf}$ gas $=11.126 \mathrm{Nm}^{3}$ gas

$=142 \mathrm{MJ}(\mathrm{HHV}$ basis $)=120 \mathrm{MJ}($ LHV basis $)$ 


\section{Abbreviations and Terms}

$\mathrm{CU}$ -

$\mathrm{CO}_{2}$-equivalence

DCFROR-

EIA -

GHG -

GWP -

HHV -

IRR -

kWh -

LHV -

$\mathrm{MJ}$ -

$\mathrm{N}_{2} \mathrm{O}-$

NGCC -

$\mathrm{Nm}^{3}-$

NREL -

PSA -

SMR -

TEAM $^{\circledR}$ -
University of Colorado

Expression of the GWP in terms of $\mathrm{CO}_{2}$ for the following three components $\mathrm{CO}_{2}$, $\mathrm{CH}_{4}, \mathrm{~N}_{2} \mathrm{O}$, based on Intergovernmental Panel on Climate Change weighting factors Discounted Cash Flow Rate of Return

Energy Information Administration

Greenhouse gas

global warming potential

higher heating value

internal rate of return

kilowatt-hour (denotes energy)

lower heating value

megajoule

nitrous oxide

natural gas combined-cycle

normal cubic meters

National Renewable Energy Laboratory

pressure swing adsorption

steam methane reforming

Tools for Environmental Analysis and Management (software by Ecobalance, Inc.) 


\subsection{Introduction}

This analysis examined hydrogen production via thermal decomposition of methane $\left[\mathrm{CH}_{4}\right.$ (gas) $\Rightarrow \mathrm{C}_{\text {(solid) }}+$ $2 \mathrm{H}_{2}$ ] using a solar reactor for two different applications: (1) for a fueling station and (2) for power production. For each application three different hydrogen production rates were examined by varying the size of the heliostat field. The fueling station application was examined as a stand-alone system. However, because storage limits the amount of hydrogen production and results in a substantial capital cost, the system was also examined as one that could supply hydrogen to a pipeline network. Based on the quality of the carbon produced at NREL's High-Flux Solar Furnace, the carbon was assumed to be sold in the carbon black market. For the power production scenario, the hydrogen is co-fired in a turbine at a natural gas combined-cycle plant. If the carbon cannot be sold then it can be used to produce additional power.

\subsection{Process Description}

The process flow diagrams for the fueling station and power production application are shown in Figures 1 and 2, respectively. In general, both systems are comprised of the same types of equipment, just different sizes and the configuration of each plant is slightly different. The solar reactor operates at atmospheric pressure. The reactor consists of an outer quartz tube and two inner concentric graphite tubes (configured vertically). The outermost graphite tube is solid, while the inner one is porous. Concentrated sunlight from a heliostat field enters through the outer quartz tube and irradiates the solid graphite tube. The solid graphite tube radiates and heats the porous tube. The natural gas is fed axially downward through the inner porous graphite tube. A fraction of the product hydrogen is recycled back through the reactor. Some of this hydrogen flows between the quartz tube and the solid graphite tube to prevent oxidation of the graphite tube and to cool the quartz. The remaining portion of the recycled hydrogen flows in the annular region between the solid and porous graphite tubes. This gas exits radially through the inner porous tube providing a fluid-wall that prevents the deposition of carbon on the inside of the reactor walls. To reduce the temperature of the products leaving the reactor, it has an expanded cooling zone that includes a jacketed portion which uses cooling water. The product hydrogen, carbon, and unconverted natural gas enter a baghouse filter where the carbon is removed. The carbon from each system is assumed to be sold in the carbon black market. Additionally, for the power production application the carbon can be burned to produce more power.

For the fueling station application, it is necessary to produce high purity hydrogen, therefore, the hydrogen and unconverted natural gas stream are fed to a pressure swing adsorption (PSA) unit. Because a minimum pressure ratio of $4: 1$ is required between the PSA feed and purge gas pressures, the hydrogen and unconverted natural gas are compressed to $0.4 \mathrm{MPa}$ (60 psi) (SRI, 1994). The PSA offgas, which is primarily methane, is recycled back to the reactor. A small purge stream is required to prevent the build up of contaminants from the natural gas (e.g., nitrogen) in the offgas loop. A slipstream of the product hydrogen is used as sweep gas for the solar reactor. Pure hydrogen must be used for this because any methane in this gas could decompose and plug the porous structure of the reactor wall. The sweep hydrogen increases the amount of hydrogen leaving the reactor, but this hydrogen is recovered and recycled so it does not affect the overall mass balance of the process. It does, however, affect the overall efficiency of the process because this gas must be compressed and heated. The product hydrogen is compressed to $20 \mathrm{MPa}(3,000 \mathrm{psi})$ and stored for use at the fueling station.

For the power production application, the hydrogen and unreacted natural gas can be burned directly in the gas turbine. A slipstream must be purified in order to supply the hydrogen sweep gas and only a small amount of hydrogen storage is needed for start-up. The purge stream from the PSA unit is also sent to the combustion turbine. Each of these streams is compressed to $2 \mathrm{MPa}(300 \mathrm{psi})$. During times when hydrogen is not being produced from the solar reactor system, the turbine runs entirely on natural gas. 
Figure 1: Process Flow Diagram for Fueling Station Application

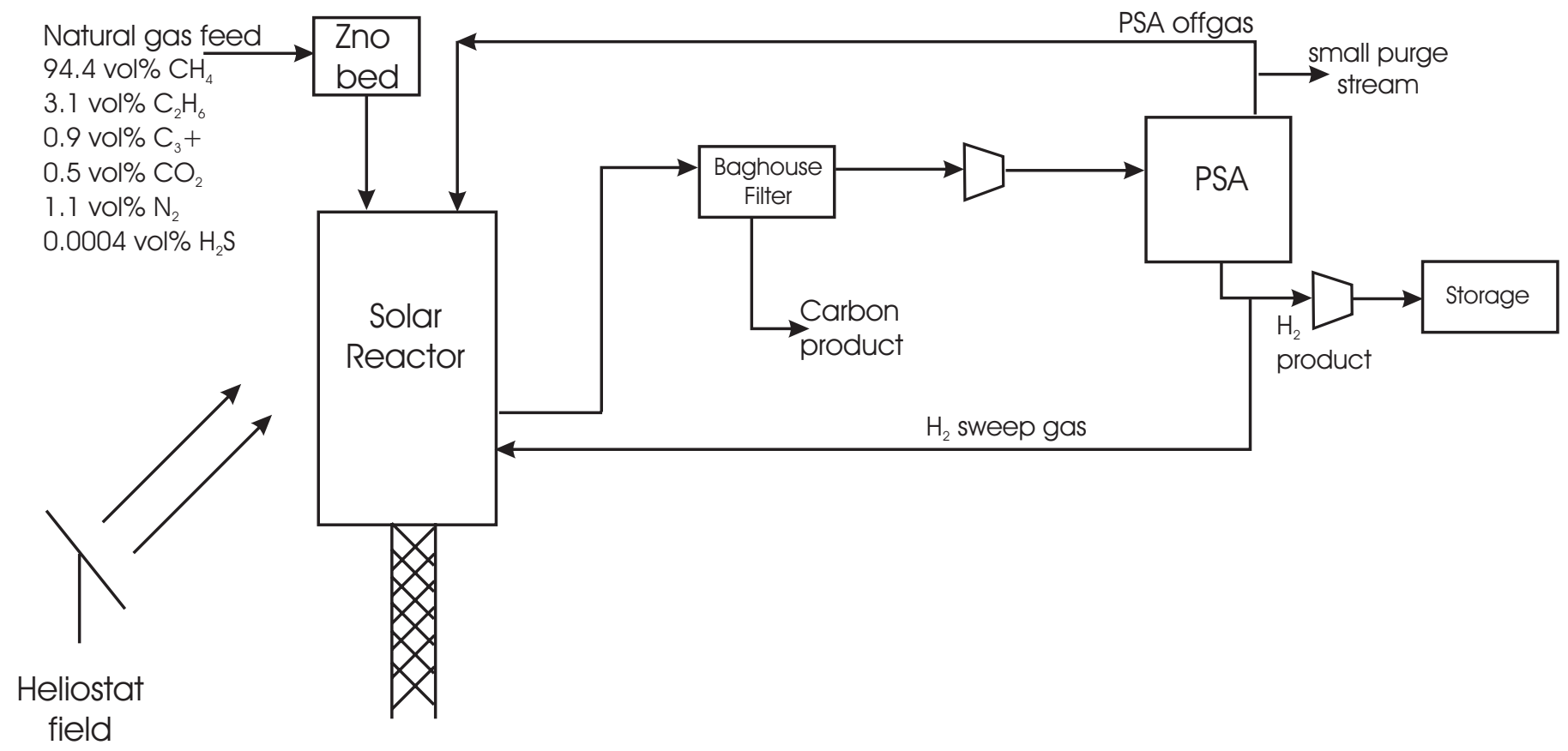

Figure 2: Process Flow Diagram for Power Application

Natural gas feed
94.4 vol\% $\mathrm{CH}_{4}$
$3.1 \mathrm{vol} \% \mathrm{C}_{2} \mathrm{H}_{6}$
$0.9 \mathrm{vol} \% \mathrm{C}_{3}+$
$0.5 \mathrm{vol} \% \mathrm{CO}_{2}$
$1.1 \mathrm{vol} \% \mathrm{~N}_{2}$
$0.0004 \mathrm{vol} \% \mathrm{H}_{2} \mathrm{~S}$

Heliostat field

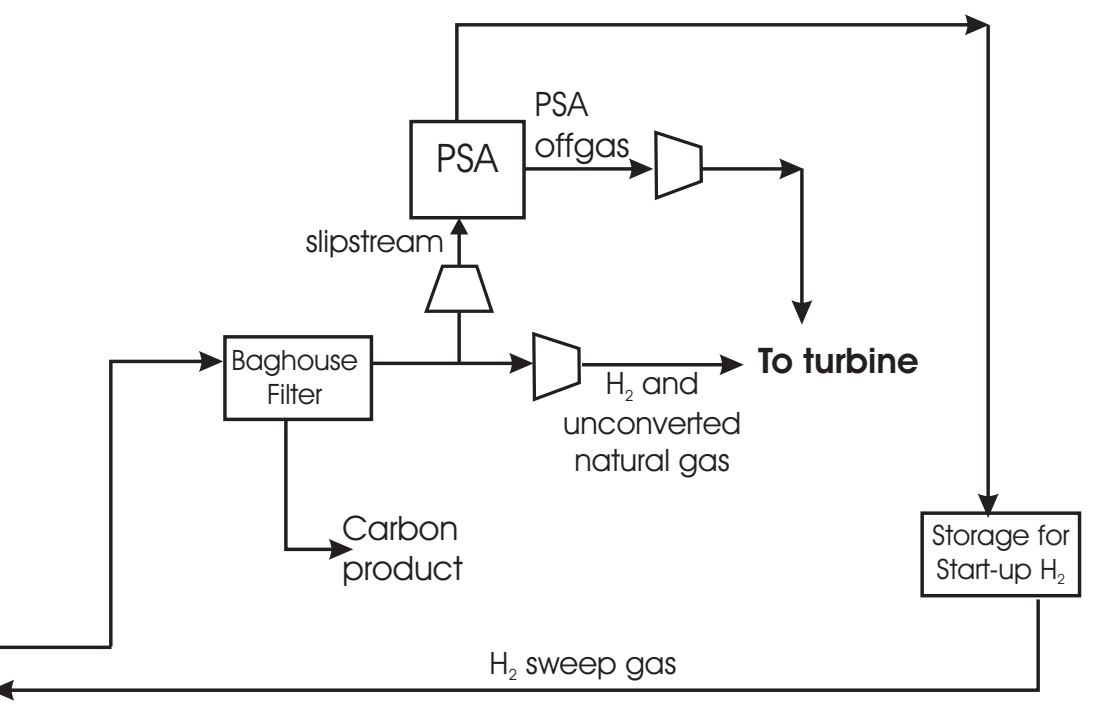


The carbon produced in the solar thermal reactor could be used for duct heating going into the heat recovery steam generator, or it could be sold.

\subsection{Solar Data}

To determine how much hydrogen will be produced for each application, hourly solar radiation data from the National Solar Radiation Data Base was used (Renewable Resource Data Center, 2001). The hourly data is needed to properly estimate real storage requirements, because the storage necessary will be determined by a few long periods of poor sunlight. Because Phoenix, Arizona is one of the most likely sites for either of these applications, the most recent solar data available for this location was used in sizing the hydrogen facilities. The most recent year available was 1990. Using the same system size, two other years were tested to see if there would be a significant difference in the amount of hydrogen produced. The years 1975 and 1985 were randomly chosen and the difference in the total amount of hydrogen that could be produced by any of the systems examined varied by $+/-5 \%$ to $8 \%$. Two other locations were also tested, Los Angeles and Chicago, including the economics and the results can be found in the sensitivity analysis (Section 9.5).

\subsection{Calculation Method}

Several steps were required in determining the annual hydrogen production for the solar thermal decomposition reactor. The first step in the calculations was to determine the methane conversion for various flow rates and temperatures using the entrained flow reactor model developed at the University of Colorado (CU) (Dahl, et al., 2002). Because variations in solar irradiance will affect the reactor operating temperature and conversion, a set single-pass conversion was maintained by varying the natural gas flow rate depending upon the solar irradiance. The other approach that could have been taken would be to set the flow rate and allow the extent of conversion to drift. However, purifying a stream containing less than $70 \mathrm{~mol} \%$ hydrogen, decreases the purity and recovery of the hydrogen. To avoid this, at low light intensities it would be necessary to recycle part of the hydrogen product back to the PSA feed stream. Thus, there would be a considerable amount of flow recycling through the purification and reactor recycle loop.

For the base case designs, a single-pass methane conversion of $70 \%$ was used $\left[\mathrm{CH}_{4}\right.$ (gas) $\left.=>\mathrm{C}_{\text {(solid) }}+2 \mathrm{H}_{2}\right]$. Reactor designs for converting $95 \%$ of the methane were initially examined, but the analysis determined that higher net hydrogen production rates could be achieved at $70 \%$ conversion for a given reactor size (See Figure 3). Because the unconverted methane is recycled back to the reactor in the fueling station scenarios or burned in the power production case, reducing the conversion does not increase the overall natural gas consumption. It primarily results in a slight increase in the operating costs due to recompression. Referring to Figure 3, at $1,623 \mathrm{~K}$ and $85 \%$ conversion, the hydrogen production rate would be $4.8 \mathrm{~mol} / \mathrm{s}$ of $\mathrm{H}_{2}$, but at $70 \%$ conversion and the same temperature of $1,623 \mathrm{~K}$, the methane feed rate can be increased to obtain a production rate of $68 \mathrm{~mol} / \mathrm{s} \mathrm{of} \mathrm{H}_{2}$. Another way to look at this is that the same hydrogen production rate can be obtained at a lower temperature (e.g., $30 \mathrm{~mol} / \mathrm{s}$ of $\mathrm{H}_{2}$ are produced at either $1,550 \mathrm{~K}$ and $70 \%$ conversion or at $1,800 \mathrm{~K}$ and $85 \%$ conversion, but $30 \mathrm{~mol} / \mathrm{s}$ of $\mathrm{H}_{2}$ can never be achieved at $95 \%$ conversion without overheating the reactor and melting the quartz).

For a given reactor size, the hydrogen sweep gas flow rate was set, then different combinations of methane flow rates and reactor wall temperatures were entered into CU's model, which resulted in a series of different conversions. The graduate student who developed the model, Jaimee Dahl, ran the model for various operating conditions and provided the data to NREL. For each temperature, there was one specific methane flow rate which gave a $70 \%$ conversion leaving the reactor. The methane flow rate versus temperature was plotted to obtain a curve for the given reactor configuration to achieve $70 \%$ 
Figure 3: Hydrogen Production Rate versus Temperature for a Fixed Conversion




conversion. Figure 4 shows the curve generated for the fueling station application. The curve will be somewhat different for different reactor geometries due to heat loss effects.

To minimize capital costs and avoid the possibility of the decomposition reaction occurring prior to entering the reactor, no preheating was done. The methane and wall gas entered the reactor at ambient temperature. The wall gas is heated as it passes through the porous reactor wall. For each combination of reactor temperature and inlet methane flow rate, as determined above (refer to Figure 4), the heat duty required to heat and achieve $70 \%$ conversion was determined. Aspen Plus ${ }^{\circledR}$ was used to calculate the sensible heating and heat of reaction. A second curve showing the heat required versus temperature was generated. See Figure 5 for the curve that was created for the fueling station application.

For each application, the size of the decomposition reactor was set and the heliostat field area was varied. As the heliostat area increases, the amount of solar energy focused on the reactor increases, resulting in higher operating temperatures and higher methane inlet flows for a given solar irradiance to obtain a conversion of $70 \%$. The maximum operating temperature of the reactor was set at 2,273 $\mathrm{K}$. Three heliostat field sizes were examined. First, the size of the heliostat field was set so that the reactor operating temperature at the highest hourly solar irradiance of the year did not exceed 2,273 K. Second, the size of the heliostat field was doubled. This meant that at low light intensities, twice the energy could be supplied to the reactor and thus more hydrogen could be produced, but at high light intensities, part of the heliostat field must be taken offline to avoid exceeding a reactor temperature of $2,273 \mathrm{~K}$. Third, the size of the heliostat field was cut in half. This was done to reduce the capital costs, but this generally resulted in much lower hydrogen production rates.

Once the heliostat area was set, the amount of energy supplied to the reactor by the primary concentrator was determined. This was done by multiplying a given solar irradiance $\left(\mathrm{W} / \mathrm{m}^{2}\right)$ by the heliostat field collection area, and then applying an efficiency factor. An efficiency of $69 \%$ was used in the calculations (Lewandowski, 2001 and Jones, 2001). Not all of this energy goes into heating the reactor because of the high radiant heat losses from the reactor. To estimate these losses, a radiant heat loss calculation was performed based on the reactor outside area and the reactor temperature. For a series of light intensities, an iterative calculation was performed to determine the specific temperature where the energy from the primary concentrator was balanced against the radiant heat losses and the heat going into the decomposition reaction. Figure 6 shows how the radiant heat losses and the reactor heat varied with temperature. The heat loss is the difference between Qtotal and Qreactor. For the series of light intensities, the inlet methane flow rate for the specific temperature was determined using Figure 4, the net hydrogen produced was calculated, and then a relationship between the amount of hydrogen produced and the solar irradiance was established. Figure 7 shows the hydrogen production rate versus the solar irradiance for $70 \%$ conversion. Note that for the different size heliostat fields, there is a minimum solar irradiance where all of the energy goes into heating the inlet gases, and there is not enough energy to react any methane. At this point, the net hydrogen production is zero so there is no reason to operate the solar reactor below this solar irradiance. Figure 7 shows the minimum to be between 15 and $60 \mathrm{~W} / \mathrm{m}^{2}$ for the three different heliostat sizes. Using the Phoenix sun data, it was determined that this occurs only 5\%-8\% of the daylight hours. For the largest heliostat field, the solar irradiance which results in a maximum temperature of $2,273 \mathrm{~K}$ is $515 \mathrm{~W} / \mathrm{m}^{2}$. Using the hourly solar radiation data for Phoenix, the solar irradiance was above $515 \mathrm{~W} / \mathrm{m}^{2}$ for $31 \%$ of the daylight hours. Although, this sounds detrimental to the process, Figure 7 clearly shows that the larger heliostat field is able to produce more hydrogen at lower light intensities.

Once a relationship between the solar irradiance and hydrogen production rate has been developed, it (Figure 7) can be used to determine the hourly production rate of hydrogen based on the hourly solar radiation data. Note that in order to produce hydrogen, the solar irradiance must be above the minimum required for the specific heliostat area. Additionally, if the solar irradiance is above the maximum 
Figure 4: Methane Flow Rate vs. Reactor Wall Temperature to Achieve $\mathbf{7 0 \%}$ Conversion

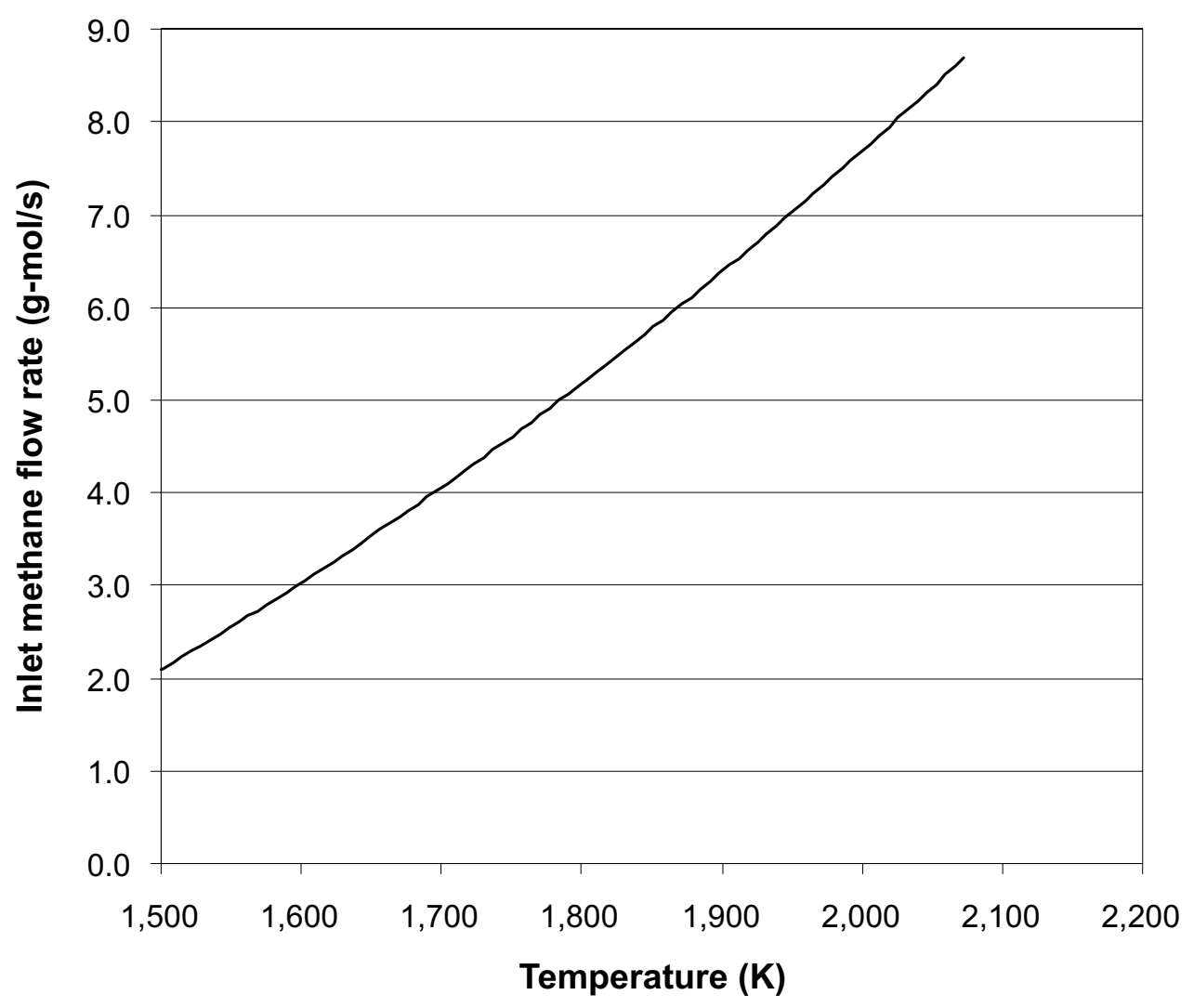

Figure 5: Reactor Heat Duty vs. Reactor Wall Temperature to Achieve $\mathbf{7 0 \%}$ Conversion

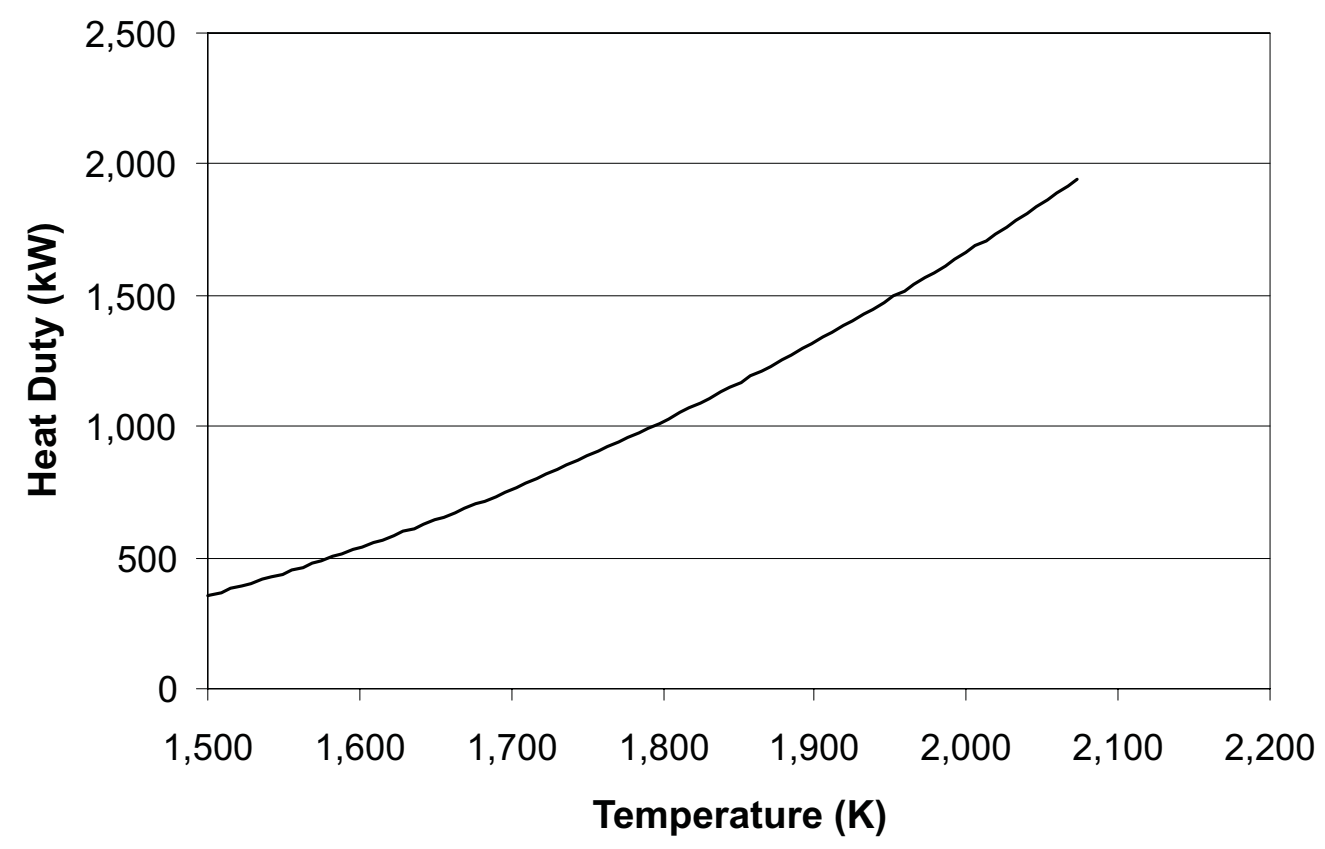


Figure 6: Duty and Heat Loss versus Temperature to Achieve 70\% Conversion for a Heliostat Size of $8,750 \mathbf{~ m}^{2}$

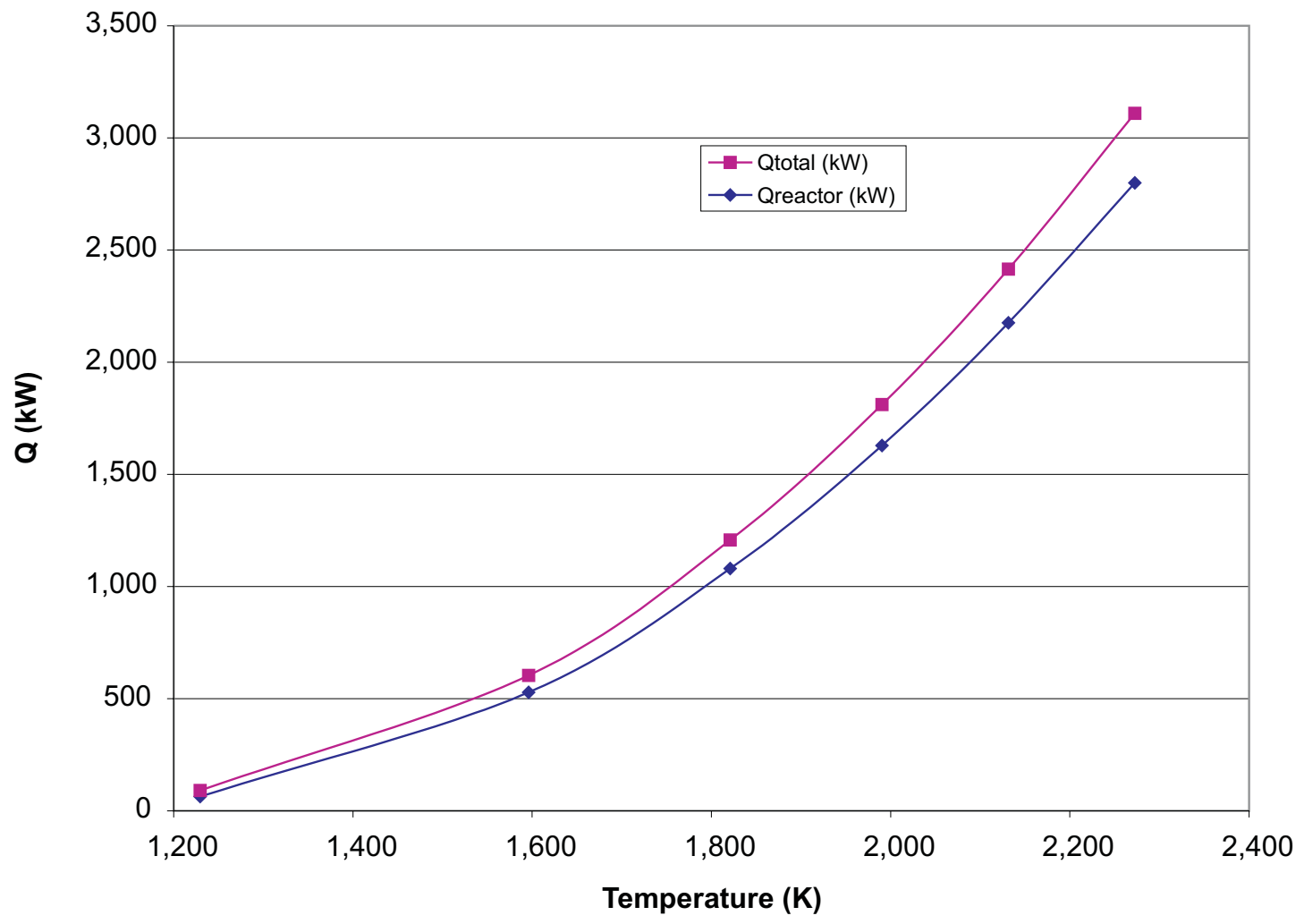

Figure 7: Hydrogen Production Rate versus Solar Irradiance to Achieve $\mathbf{7 0 \%}$ Conversion

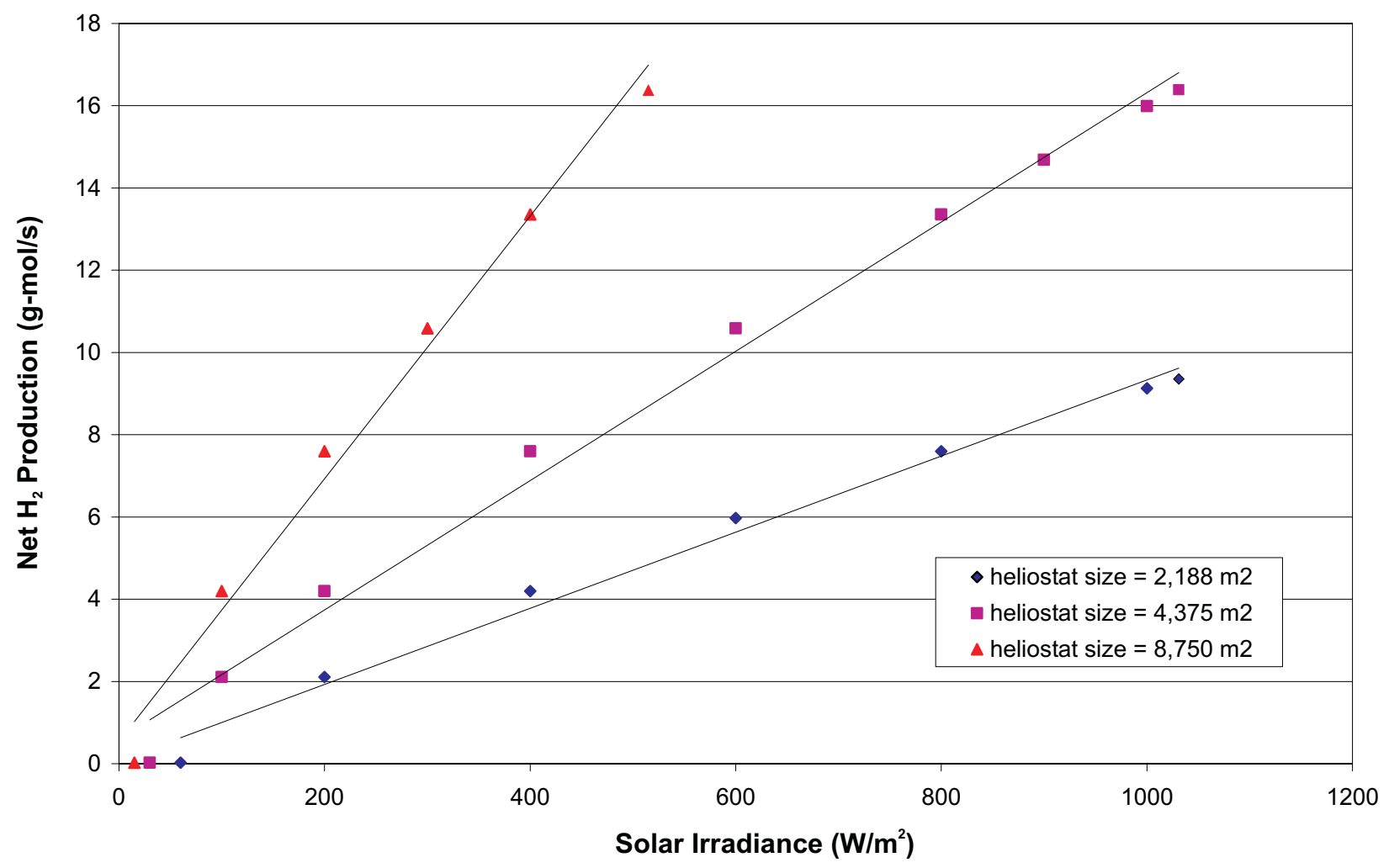


allowable, then part of the heliostat field must be taken offline so that the reactor temperature does not exceed $2,273 \mathrm{~K}$. For the service station application, where hydrogen is stored onsite, an additional check was done to make sure that hydrogen is not produced when the storage capacity was full.

For the power plant production application, a few changes in the calculation procedure were made. First, because hydrogen is needed for the sweep gas, the minimum solar irradiance was set so that the system would not operate unless there was enough sunlight to produce the required sweep gas. Additionally, there is no storage constraint. The only storage necessary is during startup, for which a compressed gas storage tank was sized to hold 2 hours worth of sweep gas.

\subsection{Economic Assumptions}

Cash flow spreadsheets were created on the basis of a Discounted Cash Flow Rate of Return (DCFROR) analysis. DCFROR is defined as the rate of return that makes the after-tax net present value equal to zero. The hydrogen selling price was calculated for a $15 \%$ after-tax internal rate of return (IRR) because this is a typical hurdle rate before a project is considered economically viable. Table 1 lists some of the economic assumptions used in the analysis. The economics in this report use 2000 U.S. dollars as the basis. The price for carbon black is that obtained in the tire industry. This is the largest market for carbon black and pricing information is readily available. In specialty markets the price will be greater, however, the size of these markets as well as the price of the carbon black is not documented. Therefore, assuming that the carbon produced by the solar reactor meets the qualifications of various specialty markets, a sensitivity analysis was performed on carbon price to determine its affect on the hydrogen selling price or cost of power (see Section 9.1). The cost basis for natural gas is the price to industrial consumers for the year 2000. Because natural gas prices have fluctuated significantly over the past several years, a sensitivity analysis was also performed on this variable and the results can be found in Section 9.3. The installed cost of the heliostat field is the projected near-term cost for large-scale production. Because the uncertainty in the price and because the heliostat field is a large part of the overall capital cost, this variable was included in the sensitivity analysis (see Section 9.2).

Table 1: Several Economic and Capital Cost Assumptions

\begin{tabular}{|l|l|}
\hline Assumption & Value \\
\hline After-tax internal rate of return & $15 \%$ \\
\hline Depreciation & Straight line \\
\hline Recovery period & 10 years \\
\hline Plant life & 20 years \\
\hline Debt/Equity & $0 \% / 100 \%$ \\
\hline Cost of electricity & $\$ 0.05 / \mathrm{kWh}^{\mathrm{a}}$ \\
\hline Price of carbon black & $\$ 0.66 / \mathrm{kg}^{\mathrm{b}}$ \\
\hline Price of natural gas & $\$ 3.72 / \mathrm{GJ}^{\mathrm{c}}$ \\
\hline Heliostat cost & $\$ 130 / \mathrm{m}^{2 \mathrm{~d}}$ \\
\hline
\end{tabular}

a EIA, 2000.

b Chemical Marketing Reporter, 2001.

c EIA, 2001.

d Jones, 2001 and U.S. Department of Energy, 1997. 


\subsection{Size and Economics of Fueling Station Application}

The fueling station application is being examined as a stand-alone system with storage as well as a system that could supply hydrogen to a pipeline network. The reactor size was set so that the outer tube diameter is 0.11 meters ( 4.3 inches) and the length is 1 meter ( $3.3 \mathrm{feet}$ ). For heliostat sizes of $2,188 \mathrm{~m}^{2}, 4,375 \mathrm{~m}^{2}$, and $8,750 \mathrm{~m}^{2}$ (as determined using the method described in Section 4.0), the total amount of hydrogen that could be produced per year equals 169 tonne/yr, 301 tonne/yr, and 416 tonne/yr, respectively. As a stand-alone system, the amount of hydrogen utilized is limited by the storage capacity. For storage amounts of $800 \mathrm{~kg}, 1,400 \mathrm{~kg}$, and 2,300 kg for the three heliostat field areas mentioned above, the daily demand that could be supplied by each refueling station is $250 \mathrm{~kg} / \mathrm{day}, 450 \mathrm{~kg} / \mathrm{day}$, and $750 \mathrm{~kg} / \mathrm{day}$ of hydrogen, respectively. For a refueling requirement of $4 \mathrm{~kg} / \mathrm{car}$, that means that roughly 63,113 , and 188 cars are fueled each day. Note that when the hydrogen storage is full, the solar reactor does not operate. Table 2 gives the hydrogen production, storage, and demand amounts for producing hydrogen from the three different heliostat sizes. There are numerous times when the storage capacity is reached and the hydrogen production system must be shutdown. For this reason, only $54 \%-66 \%$ of the total possible hydrogen production was actually produced.

Table 2: Hydrogen Production, Storage, and Demand

\begin{tabular}{|c|c|c|c|c|c|}
\hline $\begin{array}{c}\text { Heliostat } \\
\text { size }\left(\mathrm{m}^{2}\right)\end{array}$ & $\begin{array}{c}\mathrm{H}_{2} \text { produced } \\
\text { without storage } \\
\text { limit (tonne/yr) }\end{array}$ & $\begin{array}{c}\mathrm{H}_{2} \text { storage } \\
\text { capacity }(\mathrm{kg})\end{array}$ & $\begin{array}{c}\text { Daily } \mathrm{H}_{2} \\
\text { demand } \\
(\mathrm{kg} / \mathrm{day})\end{array}$ & $\begin{array}{c}\mathrm{H}_{2} \text { produced with } \\
\text { storage limit } \\
\text { (tonne/yr) }\end{array}$ & $\begin{array}{c}\text { \% produced (with } \\
\text { storage limit) of total } \\
\text { possible }\end{array}$ \\
\hline 2,188 & 169 & 800 & 250 & 91 & $54 \%$ \\
\hline 4,375 & 301 & 1,400 & 450 & 164 & $55 \%$ \\
\hline 8,750 & 416 & 2,300 & 750 & 273 & $66 \%$ \\
\hline
\end{tabular}

Because of the nature of this system, the capacity factor is low. For this discussion, the capacity factor is defined as the amount of hydrogen produced by the system in a year divided by the amount of hydrogen that could be produced if the system were able to operate continuously at its maximum rate over the course of a year. The capacity factor for the largest heliostat area is $39 \%$ without the storage limitation and $26 \%$ with the storage limitation. The capacity factor for the smaller two heliostat sizes is $28 \%$ without the storage limitation and $15 \%$ with the storage limitation.

Table 3 gives the hydrogen selling price for the three different size heliostat fields. The price ranges from $\$ 57 / \mathrm{GJ}$ to $\$ 87 / \mathrm{GJ}$ ( $\$ 8$ to $\$ 12 / \mathrm{kg}$ ) or $\$ 32$ to $\$ 49$ per fill up. It is important to note that for this application, the system would have to compete with delivered and stored hydrogen or another technology which would allow on-site production, compression, and storage. The delivered cost of hydrogen will always be greater than the plant gate price. For gaseous hydrogen produced from a large-scale, central production facility at a pressure of around $400 \mathrm{psi}$, the plant gate price is about $\$ 5-\$ 8 / \mathrm{GJ}$. In general, contract prices for delivered hydrogen are not publicly available and they vary a great deal depending on the type of delivery, quantity required, and delivery distance. SRI states that liquid hydrogen list prices have been around $\$ 45 / \mathrm{GJ}$, but that the average transaction prices are considerably below this (SRI, 2001). A typical price range for large-volume, bulk liquid consumers is $\$ 18-\$ 24 / G J$ (SRI, 2001). Of course for the refueling application, if bulk liquid delivery were used there would also be additional costs for storage, high-pressure cryogenic pumping, and revaporization. 
Table 3: Hydrogen Selling Price

\begin{tabular}{|c|c|c|c|}
\hline \multirow{2}{*}{$\begin{array}{c}\text { Heliostat } \\
\text { size }\left(\mathrm{m}^{2}\right)\end{array}$} & \multicolumn{2}{|c|}{$\mathrm{H}_{2}$ selling price } & $\begin{array}{c}\text { Cost to fill } \\
\text { fuel tank with } \\
4 \mathrm{~kg} \text { of } \mathrm{H}_{2}(\$)\end{array}$ \\
\cline { 2 - 4 } & $\begin{array}{c}(\$ / \mathrm{GJ}) \\
\text { HHV basis })\end{array}$ & $(\$ / \mathrm{kg})$ & $\$ 49$ \\
\hline 2,188 & $\$ 87$ & $\$ 12$ & $\$ 42$ \\
\hline 4,375 & $\$ 73$ & $\$ 10$ & $\$ 32$ \\
\hline 8,750 & $\$ 57$ & $\$ 8$ & \\
\hline
\end{tabular}

Note: Fill up cost is without taxes.

The operating costs, revenue, and capital cost breakdown are shown in Tables 4 and 5. Hydrogen storage is the largest capital cost accounting for $32 \%$ of the total capital cost. This is followed by the heliostat field and hydrogen compression at $21 \%$ and $19 \%$, respectively, and PSA compression at $12 \%$.

Table 4: Breakdown of Operating Costs and Revenue - Fueling Station Application

\begin{tabular}{|l|c|c|c|}
\hline Heliostat size $\left(\mathrm{m}^{2}\right)$ & 2,188 & 4,375 & 8,750 \\
\hline & \multicolumn{3}{|c|}{ Yearly cost (thousand \$) } \\
\hline Natural gas & $\$ 73$ & $\$ 131$ & $\$ 218$ \\
\hline Electricity & $\$ 26$ & $\$ 48$ & $\$ 84$ \\
\hline Other operating expenses & $\$ 44$ & $\$ 63$ & $\$ 91$ \\
\hline TOTAL OPERATING EXPENSES & $\$ 143$ & $\$ 242$ & $\$ 393$ \\
\hline \multicolumn{4}{|c|}{ Yearly revenue (million $\$$ ) } \\
\hline \multicolumn{4}{|c|}{$\$$} \\
\hline Hydrogen sales & $\$ 1.12$ & $\$ 1.71$ & $\$ 2.20$ \\
\hline Carbon sales & $\$ 0.18$ & $\$ 0.33$ & $\$ 0.54$ \\
\hline TOTAL SALES & $\$ 1.30$ & $\$ 2.04$ & $\$ 2.74$ \\
\hline
\end{tabular}

Table 5: Breakdown of Capital Costs - Fueling Station Application

\begin{tabular}{|c|c|}
\hline Heliostat size $\left(\mathrm{m}^{2}\right)$ & $\begin{array}{l}\text { Total Capital Investment } \\
\text { (million U.S.\$) }\end{array}$ \\
\hline 2,188 & $\$ 4.42$ \\
\hline 4,375 & $\$ 6.82$ \\
\hline 8,750 & $\$ 8.93$ \\
\hline & $\begin{array}{l}\text { Percent of Capital Cost } \\
\text { for } 8,750 \mathrm{~m}^{2} \text { plant }(\%)\end{array}$ \\
\hline Heliostat field & $21.4 \%$ \\
\hline Tower & $4.2 \%$ \\
\hline $\mathrm{ZnO}$ bed & $0.04 \%$ \\
\hline Solar reactor & $0.3 \%$ \\
\hline Baghouse filter & $4.2 \%$ \\
\hline PSA compressor & $12.0 \%$ \\
\hline PSA unit & $5.9 \%$ \\
\hline $\mathrm{H}_{2}$ compression & $19.3 \%$ \\
\hline $\mathrm{H}_{2}$ storage & $32.1 \%$ \\
\hline Carbon storage & $0.5 \%$ \\
\hline
\end{tabular}

Table 2, shown previously, shows that the storage limits the amount of useable hydrogen to $54 \%-66 \%$ of the maximum amount that could be produced. Increasing the size of the hydrogen storage did not significantly increase the amount of hydrogen that could be supplied for fuel. For example, using the $8,750 \mathrm{~m}^{2}$ case, by increasing the storage size from $2,300 \mathrm{~kg}$ to $3,300 \mathrm{~kg}$ (an increase of $43 \%$ ), the amount of hydrogen that could be supplied to the user only increases from $750 \mathrm{~kg} /$ day to $800 \mathrm{~kg} /$ day (an increase of $7 \%$ ). This small increase in useable hydrogen does not outweigh the large cost associated with storing 
the hydrogen. However, several options were examined to increase the productivity of the system in a cost-effective manner.

One idea was to maximize hydrogen production and to produce power via a fuel cell from the excess hydrogen. However, because of the low capacity factor for this system (capacity factor for the largest heliostat area $=39 \%$ without the storage limitation), this idea did not make economic sense. It would not be economical to have an additional large capital cost for a piece of equipment that operates only $13 \%$ of the year $(13 \%=[100 \%-66 \%] * 39 \%)$. Since this is an intermittent process, the fuel cell would have to be sized for the maximum flow rate in order to produce power from the remaining $35 \%$ of the hydrogen that cannot be used at the fueling station. The size of the fuel cell could be reduced but then additional hydrogen storage would be required (another capital cost) in order to fully utilize the remaining 35\% of the hydrogen. In reality, it would be more economical to operate the system at full capacity, flare the unused $35 \%$ of the hydrogen, and sell all of the carbon black. A different option that might benefit the solar process is to ship in hydrogen during those periods of the year when the solar irradiance is lowest, thus reducing the amount of hydrogen storage required. However, when examining the yearly hydrogen production, it was apparent that the solar irradiance is low several times throughout the year, not just a few times during the winter months. A third option was examined which increases the amount of hydrogen from the system by adding a small electric heater to provide heat to the solar reactor that can be turned on when the hydrogen supply gets low. Two scenarios using an electric heater were examined: one where the storage is kept constant and the daily demand is increased and one where the demand is kept constant and the hydrogen storage is decreased. For each scenario, the amount of hydrogen from the electric heater was varied from roughly $5 \%$ to $10 \%$ of the total amount of hydrogen produced. Table 6 shows the hydrogen production, storage, and demand with a supplemental electric heater for a heliostat size of $8,750 \mathrm{~m}^{2}$. For the constant storage scenario, producing even a small amount of hydrogen using the electric heater results in the utilization of significantly more hydrogen from the sun. Even if only 5\% of the hydrogen comes from the electric heater and the demand increases by $40 \%$, the amount of hydrogen produced from the sun increases from $66 \%$ of the total possible to $88 \%$. More hydrogen comes from the sun because the backup equipment (i.e., the electric heater) supplies hydrogen during periods of clouds or inclement weather. For the constant demand case, using the electric heater to account for $5 \%$ of the hydrogen production decreased the storage requirements by a factor of 3 (from 2,300 $\mathrm{kg}$ to $750 \mathrm{~kg}$ ).

Table 6: Hydrogen Production, Storage, and Demand with Supplemental Electric Heater

\begin{tabular}{|c|c|c|c|c|c|c|c|c|}
\hline \multirow[t]{2}{*}{$\begin{array}{l}\text { Heliostat } \\
\text { size }\left(\mathrm{m}^{2}\right)\end{array}$} & \multirow{2}{*}{$\begin{array}{l}\mathrm{H}_{2} \text { produced } \\
\text { from solar } \\
\text { without } \\
\text { storage limit } \\
\text { (tonne/yr) }\end{array}$} & \multirow[t]{2}{*}{ Scenario } & \multirow{2}{*}{$\begin{array}{c}\mathrm{H}_{2} \\
\text { storage } \\
\text { capacity } \\
(\mathrm{kg})\end{array}$} & \multirow{2}{*}{$\begin{array}{l}{\text { Daily } \mathrm{H}_{2}}_{\text {demand }} \\
\text { (kg/day) }\end{array}$} & \multicolumn{2}{|c|}{$\begin{array}{c}\mathrm{H}_{2} \text { produced from solar } \\
\text { energy input }\end{array}$} & \multicolumn{2}{|c|}{$\begin{array}{l}\mathrm{H}_{2} \text { produced from } \\
\text { electric heater }\end{array}$} \\
\hline & & & & & (tonne/yr) & $\begin{array}{l}\% \text { of total } \\
\text { possible } \\
\text { from solar }\end{array}$ & (tonne/yr) & $\begin{array}{c}\% \text { of } \\
\text { total } \\
\text { produced }\end{array}$ \\
\hline \multirow[t]{5}{*}{8,750} & \multirow[t]{5}{*}{416} & base case & 2,300 & 750 & 273 & $66 \%$ & $\mathrm{~N} / \mathrm{A}$ & N/A \\
\hline & & \multirow{2}{*}{$\begin{array}{l}\text { constant } \\
\text { storage }\end{array}$} & 2,300 & 1,050 & 365 & $88 \%$ & 17 & $4.5 \%$ \\
\hline & & & 2,300 & 1,200 & 394 & $95 \%$ & 43 & $9.8 \%$ \\
\hline & & \multirow{2}{*}{$\begin{array}{l}\text { constant } \\
\text { demand }\end{array}$} & 750 & 750 & 260 & $62 \%$ & 14 & $5.2 \%$ \\
\hline & & & 500 & 750 & 247 & $59 \%$ & 27 & $9.7 \%$ \\
\hline
\end{tabular}

Table 7 gives the hydrogen selling price with a supplemental electric heater for the cases outlined above in Table 6. Both scenarios result in a hydrogen selling price which is lower than the base case solar process. For example, using the electric heater to provide roughly $5 \%$ of the hydrogen in the constant storage case reduces the price from $\$ 57 / \mathrm{GJ}$ to $\$ 42 / \mathrm{GJ}$. Note that the small amount of hydrogen produced using the electric heater will not be cheap since the energy comes from grid electricity. But, this cost is offset by the savings in the system's total capital requirement (reduced storage) or the significant increase in total hydrogen production. 
Table 7: Hydrogen Selling Price with Supplemental Electric Heater for Heliostat Size of $8,750 \mathbf{~ m}^{\mathbf{2}}$

\begin{tabular}{|c|c|c|c|c|}
\hline \multirow[t]{2}{*}{ Scenario } & \multirow{2}{*}{$\begin{array}{c}\% \text { of } \mathrm{H}_{2} \\
\text { produced } \\
\text { from electric } \\
\text { heater }\end{array}$} & \multicolumn{2}{|c|}{$\mathrm{H}_{2}$ selling price } & \multirow{2}{*}{$\begin{array}{l}\text { Cost to fill } \\
\text { fuel tank with } \\
4 \mathrm{~kg} \text { of } \mathrm{H}_{2}(\$)\end{array}$} \\
\hline & & $\begin{array}{c}(\$ / G J) \\
\text { (HHV basis) }\end{array}$ & $(\$ / \mathrm{kg})$ & \\
\hline \multirow{2}{*}{$\begin{array}{l}\text { constant } \\
\text { storage }\end{array}$} & $4.5 \%$ & $\$ 42$ & $\$ 6.0$ & $\$ 24$ \\
\hline & $9.8 \%$ & $\$ 37$ & $\$ 5.2$ & $\$ 21$ \\
\hline \multirow{2}{*}{$\begin{array}{l}\text { constant } \\
\text { demand }\end{array}$} & $5.2 \%$ & $\$ 47$ & $\$ 6.6$ & $\$ 26$ \\
\hline & $9.7 \%$ & $\$ 45$ & $\$ 6.3$ & $\$ 25$ \\
\hline
\end{tabular}

Note: Fill up cost is without taxes.

Because storage and compression are a considerable portion of the capital cost, one other scenario was examined for this solar hydrogen production system, that is, a system that would supply hydrogen to a pipeline network. For this scenario, the hydrogen was compressed to $3 \mathrm{MPa}$ (450 psi), and it was assumed that the pipeline network already existed. Eliminating the storage limitation (i.e., maximizing hydrogen production), along with the lower capital costs, resulted in a hydrogen selling price of $\$ 18 / \mathrm{GJ}$ or $\$ 2.6 / \mathrm{kg}$ (see Table 8) for a heliostat size of $8,750 \mathrm{~m}^{2}$, which is a reduction of $68 \%$ from the base case. Note that removing the storage limitation also resulted in an increase in carbon production and thus carbon sales.

Table 8: Hydrogen Selling Price when Supplied to Hydrogen Pipeline

\begin{tabular}{|c|c|c|c|}
\hline \multirow{2}{*}{$\begin{array}{c}\text { Heliostat } \\
\text { size }\left(\mathrm{m}^{2}\right)\end{array}$} & \multirow{2}{*}{$\begin{array}{c}\mathrm{H}_{2} \text { produced from solar } \\
\text { process (tonne/yr) }\end{array}$} & \multicolumn{2}{|c|}{$\mathrm{H}_{2}$ selling price } \\
\cline { 3 - 4 } & 169 & $\$ / \mathrm{GJ}, \mathrm{HHV}$ basis $)$ & $(\$ / \mathrm{kg})$ \\
\hline 2,188 & 301 & $\$ 24$ & $\$ 3.4$ \\
\hline 4,375 & 416 & $\$ 20$ & $\$ 2.9$ \\
\hline 8,750 & & $\$ 18$ & $\$ 2.6$ \\
\hline
\end{tabular}

Note: This scenario is able to maximize hydrogen production, instead of utilizing only $54 \%-66 \%$ of the total possible hydrogen production like the stand-alone case.

\subsection{Size and Economics of Power Production Application}

For the power production application, the reactor size was set so that the outer tube diameter is 0.20 meters ( 7.9 inches) and the length is 2 meters ( 6.6 feet). The hydrogen that is produced by the system along with the unconverted methane are burned in a natural gas combined-cycle system. Remember, no purification is required for this gas stream (refer to Figure 2). The carbon that is produced can be burned to produce more power or sold in the carbon black market. The economics were examined for both options. For this analysis, there are no capital or operating costs incurred for the downstream power production equipment. Since the feedstock from the solar plant is only a small fraction of the total feed, the power production equipment is assumed to already be in place. It was assumed that the power produced from the hydrogen or hydrogen and carbon would replace an equivalent amount of power that would otherwise be produced from natural gas. Table 9 gives the hydrogen and carbon yields and the amount of power that would be produced for both options. For a $500 \mathrm{MW}$ NGCC plant, the amount of electricity that could be produced at $100 \%$ capacity is $4,380 \mathrm{GWh} / \mathrm{yr}$. Therefore, the electricity generated from the solar process only accounts for about $0.2 \%$ to $1.1 \%$ of the total output from the power plant. Additionally, it should be noted that not all of the power from the solar process is renewable because the feedstock is natural gas. Only the heat input from the solar process is renewable. For the scenario where both the hydrogen and carbon are burned, only about $9 \%$ of the electricity produced from these feedstocks is renewable. Therefore, referring to Table 9 below, only $4 \mathrm{GWh} / \mathrm{yr}$ out of the $49 \mathrm{GWh} / \mathrm{yr}$ produced by the $36,000 \mathrm{~m}^{2}$ heliostat system is renewable. Determining the amount of electricity that is renewable for the scenario where only the hydrogen is burned is more complicated. For this scenario, more natural gas 
is required per $\mathrm{kWh}$ of electricity produced because only the hydrogen is being used as a fuel and the carbon is being sold as a product.

Table 9: $\mathrm{H}_{2}$, Carbon, and Electricity Produced for Power Production Application

\begin{tabular}{|c|c|c|c|c|}
\hline $\begin{array}{c}\text { Heliostat } \\
\text { size }\left(\mathrm{m}^{2}\right)\end{array}$ & $\begin{array}{c}\mathrm{H}_{2} \text { produced } \\
\text { from solar } \\
\text { process } \\
\text { (tonne/yr) }\end{array}$ & $\begin{array}{c}\text { Carbon } \\
\text { produced from } \\
\text { solar process } \\
\text { (tonne/yr) }\end{array}$ & $\begin{array}{c}\text { Electricity produced } \\
\text { from solar process - } \\
\text { burn both } \mathrm{H}_{2} \text { and } \\
\text { carbon }(\mathrm{GWh} / \mathrm{yr})^{*}\end{array}$ & $\begin{array}{c}\text { Electricity produced } \\
\text { from solar process - } \\
\text { burn } \mathrm{H}_{2} \text { and sell } \\
\text { carbon }(\mathrm{GWh} / \mathrm{yr})^{*}\end{array}$ \\
\hline 8,500 & 692 & 2,074 & 21 & 11 \\
\hline 17,000 & 1,187 & 3,560 & 36 & 18 \\
\hline 36,000 & 1,646 & 4,938 & 49 & 25 \\
\hline
\end{tabular}

*Note: Not all of the power produced is renewable since the feedstock is natural gas.

Tables 10 and 11 give the operating costs, revenues, and capital costs for the power production application. Because hydrogen storage is not required and because the gas is only compressed to $2 \mathrm{MPa}$ (300 psi) instead of $20 \mathrm{MPa}(3,000 \mathrm{psi})$, the heliostat field is the largest cost component.

Table 10: Breakdown of Operating Costs and Revenues - Power Application

\begin{tabular}{|l|c|c|c|}
\hline Heliostat size $\left(\mathrm{m}^{2}\right)$ & 8,500 & 17,000 & 36,000 \\
\hline & \multicolumn{3}{|c|}{ Yearly cost (million $\$$ ) } \\
\hline Natural gas & $\$ 0.55$ & $\$ 0.95$ & $\$ 1.31$ \\
\hline Other operating expenses & $\$ 0.06$ & $\$ 0.12$ & $\$ 0.23$ \\
\hline TOTAL OPERATING EXPENSES & $\$ 0.61$ & $\$ 1.07$ & $\$ 1.54$ \\
\hline \multicolumn{4}{|c|}{ Yearly revenue (million $\$$ ) - Burn both $\mathrm{H}_{2}$ and Carbon Case } \\
\hline Electricity sales from $\mathrm{H}_{2}$ and carbon & $\$ 1.53$ & $\$ 2.37$ & $\$ 3.52$ \\
\hline & \multicolumn{3}{|c|}{ Yearly revenue (million $\$$ ) - Burn $\mathrm{H}_{2}$ and Sell Carbon Case } \\
\hline Electricity sales from $\mathrm{H}_{2}$ & $\$ 0.43$ & $\$ 1.37$ & $\$ 1.80$ \\
\hline Carbon sales & $\$ 0.49$ & $\$ 2.35$ & $\$ 2.84$ \\
\hline TOTAL SALES & $\$ 0.90$ & $\$ 3.26$ & $\$ 4.16$ \\
\hline
\end{tabular}

Table 11: Breakdown of Capital Costs - Power Application

\begin{tabular}{|c|c|}
\hline Heliostat size $\left(\mathrm{m}^{2}\right)$ & $\begin{array}{l}\text { Total Capital Investment } \\
\text { (million U.S.\$) }\end{array}$ \\
\hline 8,500 & $\$ 5.80$ \\
\hline 17,000 & $\$ 8.95$ \\
\hline 36,000 & $\$ 12.99$ \\
\hline & $\begin{array}{l}\text { Percent of Capital Cost } \\
\text { for } 36,000 \mathrm{~m}^{2} \text { plant }(\%)\end{array}$ \\
\hline Heliostat field & $56.1 \%$ \\
\hline Tower & $5.6 \%$ \\
\hline $\mathrm{ZnO}$ bed & $0.1 \%$ \\
\hline Solar reactor & $0.3 \%$ \\
\hline Baghouse filter & $10.4 \%$ \\
\hline PSA compressor & $5.2 \%$ \\
\hline PSA unit & $1.9 \%$ \\
\hline $\mathrm{H}_{2} / \mathrm{CH}_{4}$ compression & $18.2 \%$ \\
\hline $\begin{array}{l}\mathrm{H}_{2} \text { storage tank - } 2 \\
\text { hours of sweep gas }\end{array}$ & $2.3 \%$ \\
\hline
\end{tabular}


Because the NGCC plant is assumed to be in place prior to adding the solar process, the cost of electricity was evaluated based on that generated from the solar feedstocks (hydrogen or hydrogen and carbon) only. To determine this cost, the operating costs, revenue, and capital costs associated with the solar process were entered into the cash flow spreadsheet. Additionally, the amount of natural gas that is backed out of the gas turbine to achieve an equivalent amount of power produced from the hydrogen and carbon was accounted for. This resulted in an electricity cost that must be added to the power plant's base electricity generation price. Table 12 shows the additional cost of electricity over the base power price for the electricity produced from the solar products: (1) hydrogen or (2) hydrogen and carbon. As expected, it is more economical to sell the carbon instead of using it to produce additional power. However, in both scenarios, the cost of generating electricity using the solar process is greater than the base power price from the NGCC system. Note that this is the additional cost for the electricity generated from only the solar process feedstocks (i.e, the cost of electricity generation from the natural gas remains the same).

\section{Table 12: Power Production Cost}

\begin{tabular}{|c|c|c|}
\hline $\begin{array}{c}\text { Heliostat } \\
\text { size }\left(\mathrm{m}^{2}\right)\end{array}$ & \multicolumn{2}{|c|}{$\begin{array}{c}\text { Additional electricity cost over } \\
\text { base power production price } \\
(\ell / \mathrm{kWh})\end{array}$} \\
\cline { 2 - 3 } & $\begin{array}{c}\text { Burn both } \mathrm{H}_{2} \text { and } \\
\text { carbon }\end{array}$ & $\begin{array}{c}\text { Burn } \mathrm{H}_{2} \text { and } \\
\text { sell carbon }\end{array}$ \\
\hline 8,500 & 6.6 & 2.7 \\
\hline 17,000 & 7.1 & 3.6 \\
\hline 36,000 & 7.4 & 4.1 \\
\hline
\end{tabular}

\subsection{Energy and Greenhouse Gas Balances}

To get a true environmental picture, energy and greenhouse gas balances were calculated from a cradleto-grave perspective for each application. This means that energy and greenhouse gases from upstream process steps were included. The solar hydrogen systems were then compared to competing conventional systems. For the fueling station application, the conventional system was assumed to be natural gas steam reforming (SMR) and for the power production application, it is a NGCC system. Data for these systems were taken from two previous NREL life cycle assessments (Spath and Mann, 2000a and 2000b) and from an NREL report on hydrogen storage and transportation (Amos, 1998). In order to make an equitable comparison to the stand-alone fueling station, the SMR system assumed a central plant with liquefaction and transport over a distance of $161 \mathrm{~km}$, then high-pressure cryogenic pumping and revaporization. Figure 8 shows the results for the fueling station application. The greenhouse gas emissions are measured in terms of $\mathrm{CO}_{2}$-equivalence $\left(\mathrm{CO}_{2}\right.$-eq. $)$, where methane's greenhouse gas impact is 21 times that of $\mathrm{CO}_{2}$ and nitrous oxide's $\left(\mathrm{N}_{2} \mathrm{O}\right)$ is 310 times that of $\mathrm{CO}_{2}$ (Houghton et al., 1996). The net greenhouse gas emissions of hydrogen production via SMR are $20.4 \mathrm{~kg} \mathrm{CO}_{2}$-eq. $/ \mathrm{kg}$ of $\mathrm{H}_{2}$, compared with $3.5 \mathrm{~kg} \mathrm{CO}$-eq. $/ \mathrm{kg}$ of $\mathrm{H}_{2}$ from the stand-alone solar process. This is an $83 \%$ reduction in the global warming potential. The fossil energy consumption for the solar process is also significantly less than the SMR system at $38 \mathrm{MJ} / \mathrm{kg}$ of $\mathrm{H}_{2}$ compared to $310 \mathrm{MJ} / \mathrm{kg}$ of $\mathrm{H}_{2}$ for the SMR system. Note that liquefaction or compression consumes a large amount of fossil energy and thus, there are a significant amount of upstream greenhouse gases emitted per $\mathrm{kg}$ of $\mathrm{H}_{2}$ produced. Because the carbon is assumed to be used as a product in the carbon black industry, the solar process subtracted out the greenhouse gases and energy required to produce carbon black via crude oil. These greenhouse gases and fossil energy consumption are avoided by making the carbon black via the solar process instead of the conventional route. About $95 \%$ of the total U.S. production of carbon black uses a heavy aromatic feedstock from petroleum refining in the furnace black process (SRI,1999). The information for the carbon black production step came from the database in a life cycle assessment software package by Ecobalance, Tools for Environmental Analysis and Management $\left(\mathrm{TEAM}^{\circledR}\right)$. 


\section{Figure 8: Greenhouse Gas and Energy Balance - Fueling Station Application}
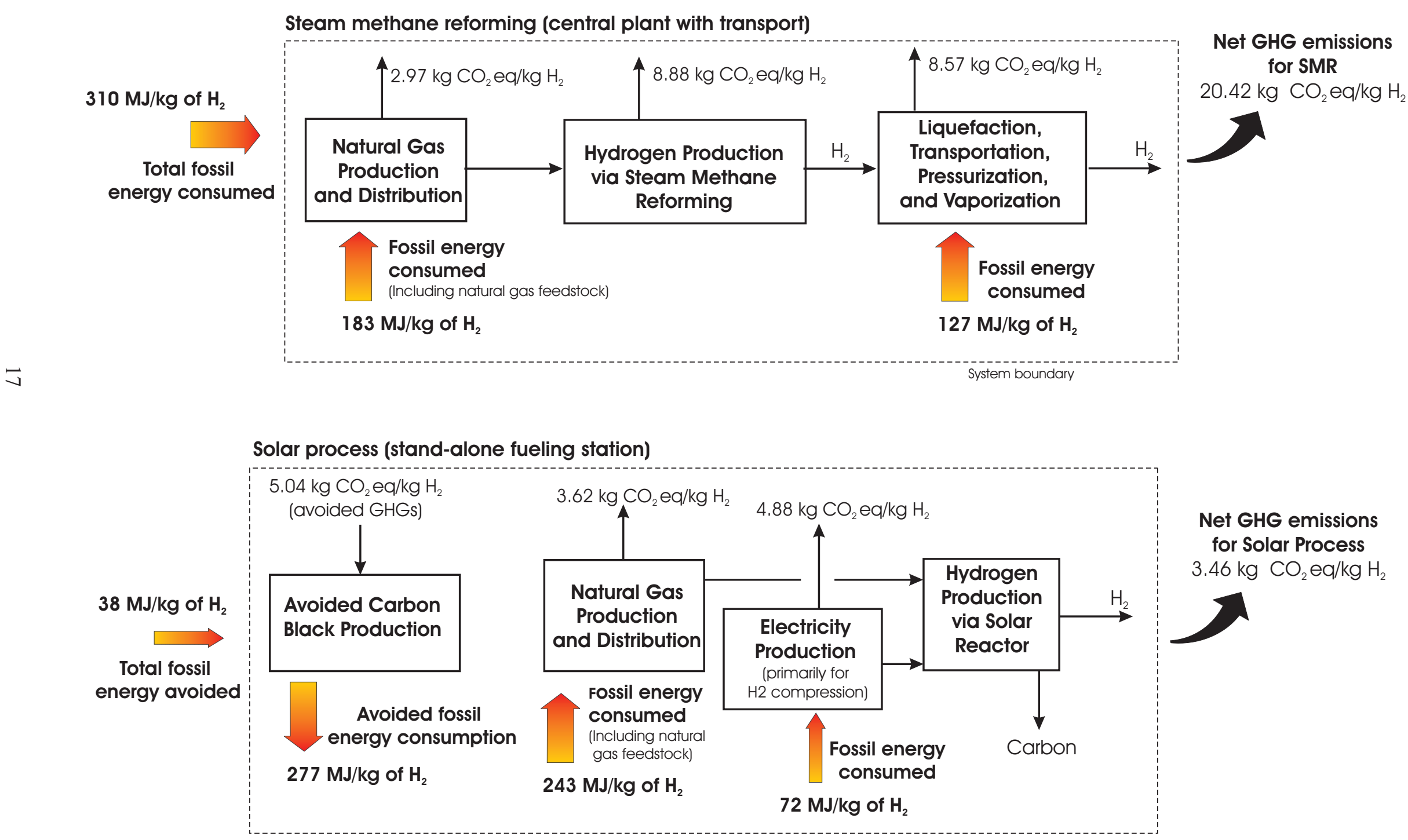

Net GHG emissions

for Solar Process

$3.46 \mathrm{~kg} \mathrm{CO}$ eq $/ \mathrm{kg} \mathrm{H}_{2}$ 
Because the power production application examined two scenarios: (1) the carbon is sold in the carbon black market and (2) the carbon is burned to produce more power, it was necessary to determine the energy and greenhouse gas balances for both scenarios. Figure 9 shows the results for both scenarios as well as the conventional system. The net greenhouse gas emissions of electricity production via NGCC are $499 \mathrm{~g} \mathrm{CO}_{2}$-eq./ $/ \mathrm{kWh}$ of electricity. Adding the solar thermal process where the carbon is burned to produce more electricity, results in greenhouse gas emissions of $456 \mathrm{~g} \mathrm{CO}_{2}$-eq. $/ \mathrm{kWh}$ (a $9 \%$ reduction). For this scenario, the fossil energy consumption is reduced from $8.3 \mathrm{MJ}$ consumed $/ \mathrm{kWh}$ to $7.8 \mathrm{MJ}$ consumed $/ \mathrm{kWh}$. Again, for the scenario where the carbon is used in the carbon black market, the greenhouse gases and energy that are avoided must be subtracted. For this scenario, both the net greenhouse gas emissions and the fossil energy consumption are negative at $-576 \mathrm{~g} \mathrm{CO}_{2}$-eq. $/ \mathrm{kWh}$ and -4.8 MJ consumed/kWh, respectively.

\subsection{Sensitivity Analysis}

Several variables were examined in the sensitivity analysis. Because of the various software programs and modeling interactions required to assess this process, Monte Carlo Analysis could not be performed. Therefore, each variable was changed independently of the others. The variables that were examined are (1) carbon selling price, (2) heliostat cost, (3) price of natural gas, and (4) greenhouse gas credit. The results of the sensitivity analysis are given in the following sections.

\subsection{Price of Carbon Black}

The largest market for carbon black is the tire industry, which consumes $70 \%$ of the carbon black produced worldwide or 7.9 million tonnes/yr (SRI, 1999). The second largest market for carbon black is the industrial rubber products industry, which consumes the majority of the remaining carbon black $(20 \%$ of the carbon black produced worldwide). There are also other possible miscellaneous uses and specialty markets. The price of carbon black in these other markets is usually higher than that for the tire industry. However, specialty grades must be produced and their qualifications often depend on the surface area, particle size, and structure of the carbon black particles. Purchased costs as quoted by Mozel, Inc., a distributor for Cabot Corporation, show that the price of carbon black could range from roughly $\$ 1.75 / \mathrm{kg}$ to $\$ 3.30 / \mathrm{kg}$ for products such as Monarch 120 A58, Monarch 800, Elftex 12, Regal 300R and 330R, and Vulcan XC 72 (Russell, 2002). However, this quote is for carbon delivered in $11 \mathrm{~kg}(25 \mathrm{lb})$ bags and these prices are also for large quantities, not bulk, which means buying 400 or more bags. NREL's analysis does not include the cost to bag or deliver the carbon. Instead, it assumes that the carbon is put in barrels or railcars and that the transport cost is paid by the purchaser. Currently, the market size for most of the various types of carbon black mentioned above are less than 0.5 million $\mathrm{kg} / \mathrm{yr}$ for each type mentioned (Hamilton, 2001). Additionally, there are two other carbon markets (graphitic and activated carbon) which could be pursued and the carbon price for these markets ranges from $\$ 0.22$ to $\$ 1.90$ per $\mathrm{kg}$ (Lane, 2001). Therefore, a sensitivity analysis was performed to examine the hydrogen selling price relative to the price of carbon.

Figure 10 shows the hydrogen selling price relative to the price of carbon for a $15 \%$ after-tax IRR for the fueling station application with storage limitations and a heliostat size of $8,750 \mathrm{~m}^{2}$. The graph shows that if the carbon could be sold for $\$ 1.50 / \mathrm{kg}$ instead of $\$ 0.66 / \mathrm{kg}$ then the price of the hydrogen would drop from $\$ 57 / \mathrm{GJ}$ to $\$ 38 / \mathrm{GJ}$ (a decrease of $32 \%$ ). The carbon price was increased until the hydrogen selling price from the system was zero. At this point the carbon price must be equal to $\$ 3.33 / \mathrm{kg}$. 
Figure 9: Greenhouse Gas and Energy Balance - Power Production Application
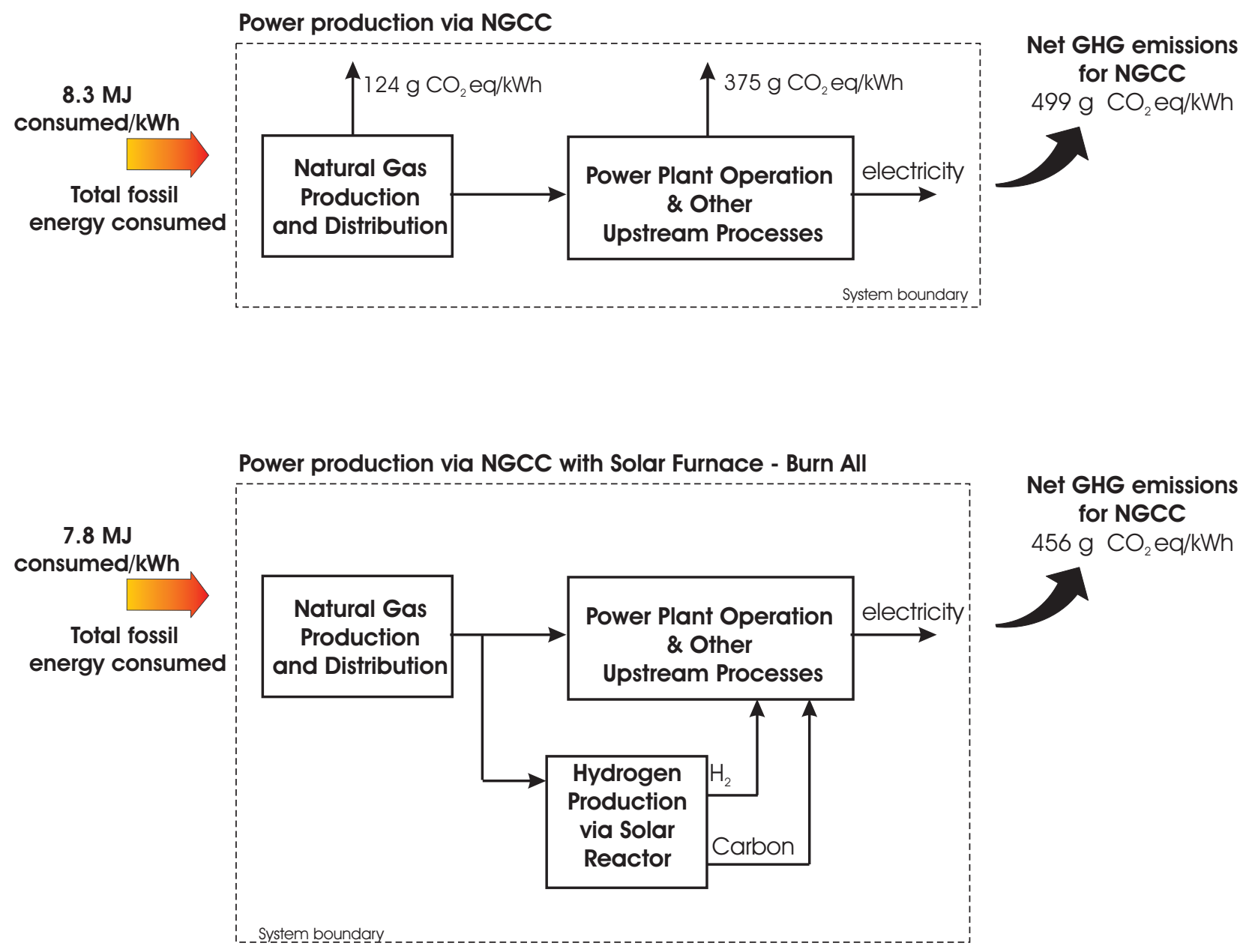

Power production via NGCC with Solar Furnace - Burn $\mathrm{H}_{2}$ ONLY

$-4.8 \mathrm{MJ}$ consumed/kWh

Total fossil energy consumed
$336 \mathrm{~kg} \mathrm{CO}$ eq/kWh

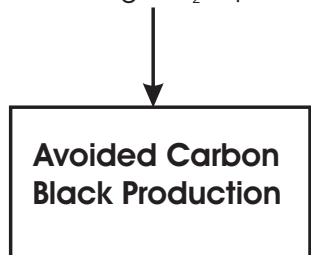

Avoided fossil energy consumption

$18.4 \mathrm{MJ} / \mathrm{kWh}$

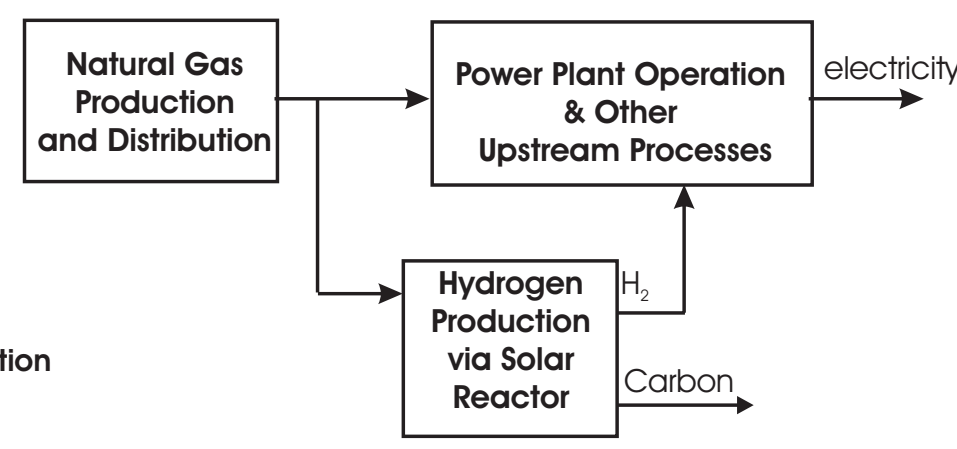

System boundary
Net GHG emissions for NGCC

$-576 \mathrm{~g} \mathrm{CO}_{2}$ eq/kWh 
Figure 10: Hydrogen Selling Price vs. Carbon Price (15\% IRR) for Fueling Station Application and Heliostat Size of $8,750 \mathrm{~m}^{2}$

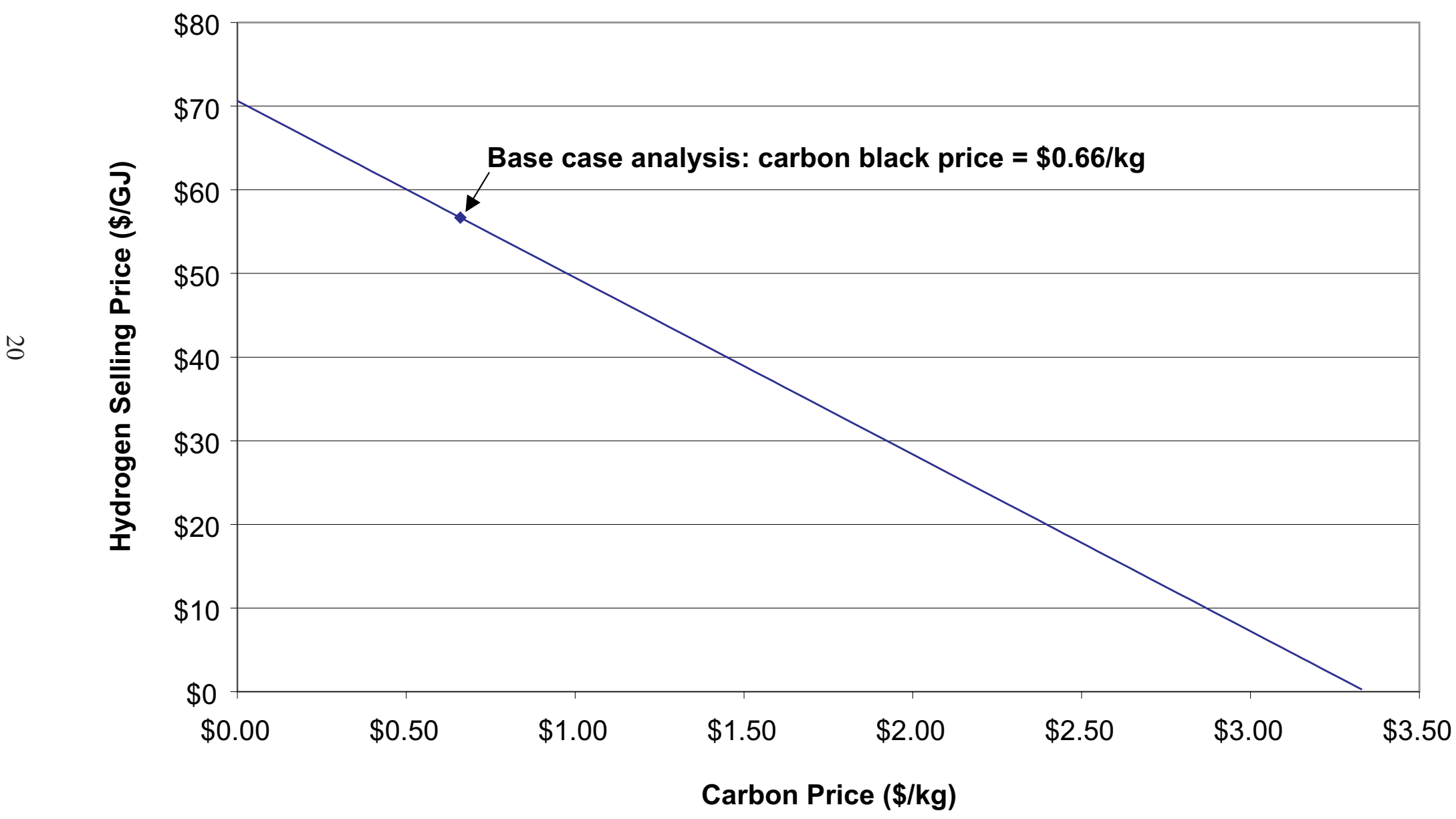


The price of carbon black was also varied for the power production application (obviously, this was only done for the burn hydrogen and sell carbon case). Figure 11 shows the results for the heliostat size of $8,500 \mathrm{~m}^{2}$ with three points marked: (1) the base case, (2) the point where selling the carbon black would be cost equivalent to burning it, and (3) the point where the price of carbon black results in an electricity cost that is equivalent to the base price. The carbon price for points 2 and 3 will be similar for the cases with the larger heliostat fields. For a carbon price greater than $\$ 0.80 / \mathrm{kg}$ the cost to produce electricity from the solar thermal process is actually less than the power generation cost from the combined-cycle system using natural gas. However, it is important to note that this is for the power produced from the solar thermal feedstock only. Therefore, although a carbon price of $\$ 1.00 / \mathrm{kg}$ results in an electricity price that is $5 \phi / \mathrm{kWh}$ less than the power plant's base electricity price, for a $500 \mathrm{MW}$ system the amount of power produced from the solar feedstock is less than $1 \%$ of the total electricity produced (see Section 7.0). Consequently, overall the solar process will not significantly reduce the cost of electricity from the power plant. However, a small portion of the power from the plant would be renewable.

Table 13 and 14 examine the percent of the carbon market captured for each application for a specific number of plants and carbon market sizes. The market size of 0.6 million tonnes is the total size of all specialty carbon black markets worldwide excluding the tire market and industrial rubber products market. For the largest heliostat size, it would take 100 fueling station size plants to reach $13 \%-20 \%$ of the market share. However, if the carbon produced from the solar process is only applicable to a market size that is 0.16 million tonnes/yr (current U.S. consumption of non-tire, non-rubber carbon black (SRI, 1999)), it takes only 25 plants to reach $13 \%-20 \%$ of the market share. As mentioned previously, the size of most of the specialty carbon black markets is less than 0.5 million $\mathrm{kg} / \mathrm{yr}(0.0005$ million tonnes/yr) for each type. For the power production application, 25 plants at the large heliostat size produce enough carbon to cover $20 \%$ of the current worldwide specialty market. For a market size of 0.16 million tonnes/yr, it takes only 6 plants to reach a market share of 19\%. It will be important to determine exactly which markets the carbon product from the solar process is applicable to, how large those markets are, and what the ultimate selling price would be.

Table 13: Examining Market Share for Fueling Station Application

\begin{tabular}{|c|c|c|c|c|c|c|c|c|}
\hline \multirow{2}{*}{$\begin{array}{c}\text { Heliostat } \\
\text { size }\left(\mathrm{m}^{2}\right)\end{array}$} & \multicolumn{3}{|c|}{ Without storage limit } & \multicolumn{4}{c|}{ With storage limit } \\
\cline { 2 - 9 } & $\begin{array}{c}\text { Market size of } \\
0.6 \text { million tonnes/yr }\end{array}$ & \multicolumn{2}{c|}{$\begin{array}{c}\text { Market size of } \\
0.16 \text { million tonnes/yr }\end{array}$} & $\begin{array}{c}\text { Market size of } \\
0.6 \text { million tonnes/yr }\end{array}$ & \multicolumn{2}{c|}{$\begin{array}{c}\text { Market size of } \\
0.16 \text { million tonnes/yr }\end{array}$} \\
\cline { 2 - 9 } & $\begin{array}{c}\text { \# of } \\
\text { plants }\end{array}$ & $\begin{array}{c}\% \text { of } \\
\text { market }\end{array}$ & $\begin{array}{c}\text { \# of } \\
\text { plants }\end{array}$ & $\begin{array}{c}\% \text { of } \\
\text { market }\end{array}$ & $\begin{array}{c}\text { \# of } \\
\text { plants }\end{array}$ & $\begin{array}{c}\% \text { of } \\
\text { market }\end{array}$ & $\begin{array}{c}\text { \# of } \\
\text { plants }\end{array}$ & $\begin{array}{c}\% \text { of } \\
\text { market }\end{array}$ \\
\hline 2,188 & 100 & $8 \%$ & 25 & $8 \%$ & 100 & $4 \%$ & 25 & $4 \%$ \\
\hline 4,375 & 100 & $14 \%$ & 25 & $14 \%$ & 100 & $8 \%$ & 25 & $8 \%$ \\
\hline 8,750 & 100 & $20 \%$ & 25 & $20 \%$ & 100 & $13 \%$ & 25 & $13 \%$ \\
\hline
\end{tabular}

Note: For the tire industry, 100 plants would be only $1 \%$ to $2 \%$ of the market share.

Table 14: Examining Market Share for Power Production Application

\begin{tabular}{|c|c|c|c|c|}
\hline $\begin{array}{c}\text { Heliostat } \\
\text { size }\left(\mathrm{m}^{2}\right)\end{array}$ & \multicolumn{2}{|c|}{$\begin{array}{c}\text { Market size of } \\
0.6 \text { million tonnes/yr }\end{array}$} & \multicolumn{2}{c|}{$\begin{array}{c}\text { Market size of } \\
0.16 \text { million tonnes/yr }\end{array}$} \\
\cline { 2 - 5 } & $\begin{array}{c}\text { \# of } \\
\text { plants }\end{array}$ & $\begin{array}{c}\text { \% of } \\
\text { market }\end{array}$ & $\begin{array}{c}\text { \# of } \\
\text { plants }\end{array}$ & $\begin{array}{c}\% \text { of } \\
\text { market }\end{array}$ \\
\hline 8,500 & 25 & $8 \%$ & 6 & $8 \%$ \\
\hline 17,000 & 25 & $14 \%$ & 6 & $13 \%$ \\
\hline 36,000 & 25 & $20 \%$ & 6 & $19 \%$ \\
\hline
\end{tabular}

Note: For the tire industry, 25 plants would be only $1 \%$ to $2 \%$ of the market share. 
Figure 11: Additional Price to Base Electricity Cost vs. Carbon Price (15\% IRR) for the Power Application and Heliostat Size of $8,500 \mathrm{~m}^{2}$

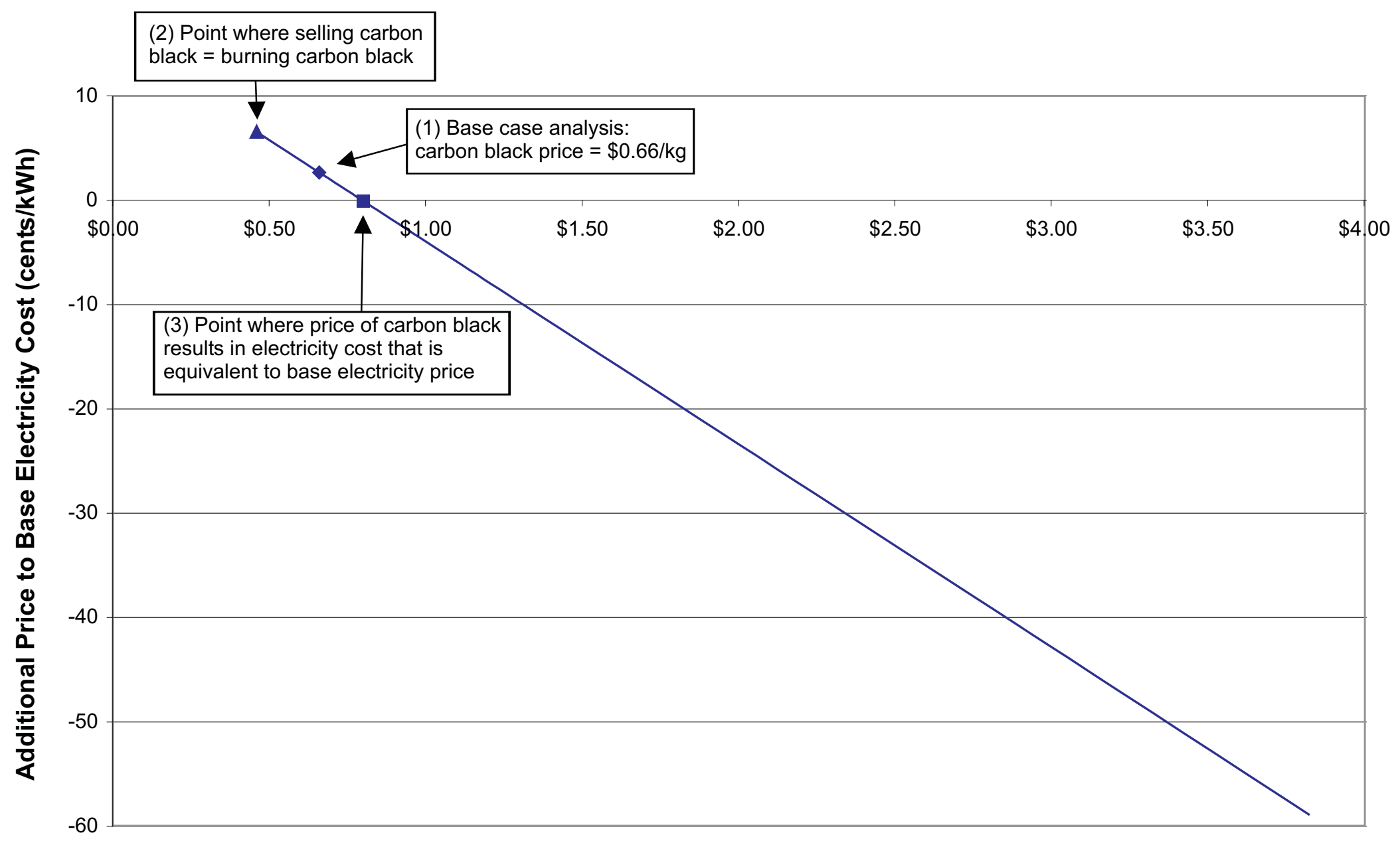

Carbon Price $(\$ / \mathrm{kg})$ 


\subsection{Heliostat Cost}

Due to its uncertainty and because the cost of the heliostat field is a large portion of the total capital investment, a sensitivity analysis was performed to determine its affect on the economics. The heliostat cost was varied from its base case value of $\$ 130 / \mathrm{m}^{2}$, which is the near-term expected installed cost, to a projected cost of $\$ 75 / \mathrm{m}^{2}$ (Jones, 2001 and U.S. Department of Energy, 1997), and a high value of $\$ 250 / \mathrm{m}^{2}$ (U.S. Department of Energy, 1997 and Falcone, 1986). Table 15 gives the resulting hydrogen selling price for the fueling station application and Table 16 gives the results for the power production application. Because of the large cost associated with compressing and storing the hydrogen, reducing the heliostat cost did not significantly reduce the hydrogen selling price for the fueling station application (only $5 \%$ to $11 \%$ ). This variable had a larger affect on the power production application because storage is not required and the hydrogen is compressed to a much lower pressure. Table 16 shows that the medium size plant is affected the most by a change in the heliostat cost. This is the plant where the size of the heliostat field was determined such that the maximum reactor temperature is reached at the highest hourly solar irradiance of the year. The smaller size plant reduces the amount of heliotstat area and thus the capital cost, but the amount of hydrogen and carbon produced is also reduced. Note, however, the decreases are not proportional and thus the revenue from selling the hydrogen and carbon diminishes the effect of changing the heliostat cost. A similar situation is true for the plant with the largest heliostat size. The plant incurs a higher capital cost for an increase in the production of hydrogen and carbon but again, the increase is not proportional.

Table 15: Fueling Station Application - Sensitivity to Heliostat Cost

\begin{tabular}{|c|c|c|c|}
\hline \multirow{2}{*}{$\begin{array}{c}\text { Heliostat } \\
\text { size }\left(\mathrm{m}^{2}\right)\end{array}$} & \multicolumn{3}{|c|}{$\mathrm{H}_{2}$ selling price (\$/GJ, HHV basis) } \\
\cline { 2 - 4 } & $\begin{array}{c}\text { Base case } \\
\text { heliostat cost of } \\
\$ 130 / \mathrm{m}^{2}\end{array}$ & $\begin{array}{c}\text { Low heliostat } \\
\text { cost of } \\
\$ 75 / \mathrm{m}^{2}\end{array}$ & $\begin{array}{c}\text { High heliostat } \\
\text { cost of } \\
\$ 250 / \mathrm{m}^{2}\end{array}$ \\
\hline 2,188 & 87 & 82 & 97 \\
\hline 4,375 & 73 & 68 & 84 \\
\hline 8,750 & 57 & 50 & 70 \\
\hline
\end{tabular}

Table 16: Power Production Application - Sensitivity to Heliostat Cost

\begin{tabular}{|c|c|c|c|c|c|c|}
\hline \multirow{2}{*}{$\begin{array}{c}\text { Heliostat } \\
\text { size }\left(\mathrm{m}^{2}\right)\end{array}$} & \multicolumn{4}{|c|}{ Additional electricity cost over base power production price $(\varnothing / \mathrm{kWh})$} \\
\cline { 2 - 7 } & \multicolumn{2}{|c|}{ Burn both $\mathrm{H}_{2}$ and carbon } & \multicolumn{3}{c|}{ Burn $\mathrm{H}_{2}$ and sell carbon } \\
\cline { 2 - 7 } & $\begin{array}{c}\text { Base case } \\
\text { heliostat } \\
\text { cost of } \\
\$ 130 / \mathrm{m}^{2}\end{array}$ & $\begin{array}{c}\text { Low } \\
\text { heliostat } \\
\text { cost of } \\
\$ 75 / \mathrm{m}^{2}\end{array}$ & $\begin{array}{c}\text { High } \\
\text { heliostat } \\
\text { cost of } \\
\$ 250 / \mathrm{m}^{2}\end{array}$ & $\begin{array}{c}\text { Base case } \\
\text { heliostat } \\
\text { cost of } \\
\$ 130 / \mathrm{m}^{2}\end{array}$ & $\begin{array}{c}\text { Low } \\
\text { heliostat } \\
\text { cost of } \\
\$ 75 / \mathrm{m}^{2}\end{array}$ & $\begin{array}{c}\text { High } \\
\text { heliostat } \\
\text { cost of } \\
\$ 250 / \mathrm{m}^{2}\end{array}$ \\
\hline 8,500 & 6.6 & 5.3 & 9.5 & 2.7 & 0.089 & 8.3 \\
\hline 17,000 & 7.1 & 5.2 & 11.3 & 3.6 & -0.17 & 11.8 \\
\hline 36,000 & 7.4 & 6.2 & 9.8 & 4.1 & 1.8 & 9.0 \\
\hline
\end{tabular}

Note: The medium size plant is affected the most by a change in the heliostat cost.

\subsection{Price of Natural Gas}

Changing the price of the natural gas did not have a significant effect on the analysis for either application. However, for the power production application, because it is more economical to sell the carbon than burn it, an increase or decrease in the price of natural gas did have a greater effect on the cost of electricity for that scenario. The results of the fueling station application and power production application are shown in Table 17 and 18, respectively. For the fueling station application, an increase or decrease in the price of the natural gas changed the hydrogen selling price by less than $+/-3 \%$. 
Table 17: Fueling Station Application - Sensitivity to the Price of Natural Gas

\begin{tabular}{|c|c|c|c|}
\hline \multirow{2}{*}{$\begin{array}{c}\text { Heliostat } \\
\text { size }\left(\mathrm{m}^{2}\right)\end{array}$} & \multicolumn{3}{|c|}{$\mathrm{H}_{2}$ selling price $(\$ / \mathrm{GJ}, \mathrm{HHV}$ basis) } \\
\cline { 2 - 4 } & $\begin{array}{c}\text { base case price } \\
\text { of natural gas }= \\
\$ 3.72 / \mathrm{GJ}\end{array}$ & $\begin{array}{c}\text { low price of } \\
\text { natural gas }= \\
\$ 2.50 / \mathrm{GJ}\end{array}$ & $\begin{array}{c}\text { high price of } \\
\text { natural gas }= \\
\$ 5.00 / \mathrm{GJ}\end{array}$ \\
\hline 2,188 & 87 & 85 & 89 \\
\hline 4,375 & 73 & 71 & 75 \\
\hline 8,750 & 57 & 55 & 59 \\
\hline
\end{tabular}

Table 18: Power Production Application - Sensitivity to Price of Natural Gas

\begin{tabular}{|c|c|c|c|c|c|c|}
\hline \multirow{2}{*}{$\begin{array}{c}\text { Heliostat } \\
\text { size }\left(\mathrm{m}^{2}\right)\end{array}$} & \multicolumn{4}{|c|}{ Additional electricity cost over base power production price $(\phi / \mathrm{kWh})$} \\
\cline { 2 - 7 } & $\begin{array}{c}\text { Burn both } \mathrm{H}_{2} \text { and carbon } \\
\text { of case price } \\
\text { of natural gas } \\
=\$ 3.72 / \mathrm{GJ}\end{array}$ & $\begin{array}{c}\text { low price of } \\
\text { natural gas }= \\
\$ 2.50 / \mathrm{GJ}\end{array}$ & $\begin{array}{c}\text { high price of } \\
\text { natural gas } \\
\$ 5.00 / \mathrm{GJ}\end{array}$ & $\begin{array}{c}\text { base case price } \\
\text { of natural gas } \\
=\$ 3.72 / \mathrm{GJ}\end{array}$ & $\begin{array}{c}\text { low price of } \\
\text { natural gas }= \\
\$ 2.50 / \mathrm{GJ}\end{array}$ & $\begin{array}{c}\text { high price of } \\
\text { natural gas }= \\
\$ 5.00 / \mathrm{GJ}\end{array}$ \\
\hline 8,500 & 6.6 & 6.5 & 6.7 & 2.7 & 2.0 & 3.4 \\
\hline 17,000 & 7.1 & 7.0 & 7.3 & 3.6 & 2.9 & 4.3 \\
\hline 36,000 & 7.4 & 7.3 & 7.4 & 4.1 & 3.4 & 4.8 \\
\hline
\end{tabular}

\subsection{Greenhouse Gas Credit}

Because the solar process produces less GHGs per kg of hydrogen produced or per $\mathrm{kWh}$ of electricity produced, applying a credit for fewer emissions was examined as a sensitivity case. This did not have a large effect on either application. For the fueling station application, even at a credit of $\$ 20 /$ tonne of $\mathrm{CO}_{2}$-eq, the hydrogen selling price is only reduced from $\$ 57 / \mathrm{GJ}$ to $\$ 54 / \mathrm{GJ}$ for the system with a heliostat size of $8,750 \mathrm{~m}^{2}$. Looking at Figure 7, from a life cycle perspective, the solar process saves about $17 \mathrm{~kg}$ of $\mathrm{CO}_{2}$-eq emissions $/ \mathrm{kg}$ of $\mathrm{H}_{2}$. With the storage limitation, this system produces 273 tonne/yr of $\mathrm{H}_{2}$; therefore, the GHG reduction is 4,641 tonne/yr and thus the GHG credit is only $\$ 92,820 / y$. This number is considerably less than the revenue from selling the hydrogen and carbon, \$2.2 million and \$0.54 million, respectively (see Table 4). For the power application, the burn $\mathrm{H}_{2}$ only case has the largest benefit, but at $\$ 20 /$ tonne of $\mathrm{CO}_{2}$-eq, the additional cost of electricity over the base power price for the solar fraction is only reduced from $2.7 \notin / \mathrm{kWh}$ to $2.5 \phi / \mathrm{kWh}$.

\subsection{Other Locations}

Because the amount of solar radiation varies at other locations throughout the United States, hourly solar radiation data for two other sites for the year 1990 were also applied to the filling station application. Los Angeles, California was chosen as another likely place to locate one of these facilities. The system sizes as determined by the solar data for Phoenix were keep constant and, depending on the size of the heliostat field, the total potential amount of hydrogen that could be produced from the system decreased by $13 \%$ to $23 \%$. If the storage size is kept the same as that for the Phoenix analysis, then the amount of hydrogen produced with the storage limitation decreases by about $27 \%$ for each heliostat size. For the Los Angeles area, the hydrogen selling price was calculated for both the storage limitation case and for a system where hydrogen is supplied to a pipeline network. The results are shown in Table 19. The hydrogen selling price is about $40 \%$ greater than the Phoenix case with the storage limitation (e.g., $\$ 79 /$ GJ versus $\$ 57 / G J$ for the $8,750 \mathrm{~m}^{2}$ case). However, the price is only $20 \%$ greater (e.g., $\$ 22 / \mathrm{GJ}$ versus $\$ 18 / \mathrm{GJ}$ for the 8,750 $\mathrm{m}^{2}$ case) for the case where the hydrogen production is maximized and the hydrogen is put in a pipeline. 
Table 19: Hydrogen Production, Storage, Demand, and $\mathrm{H}_{2}$ Selling Price - Los Angeles

\begin{tabular}{|c|c|c|c|c|c|c|}
\hline \multirow{2}{*}{$\begin{array}{l}\text { Heliostat } \\
\text { size }\left(\mathrm{m}^{2}\right)\end{array}$} & \multirow{2}{*}{$\begin{array}{l}\mathrm{H}_{2} \text { produced } \\
\text { without } \\
\text { storage limit } \\
\text { (tonne/yr) }\end{array}$} & \multirow{2}{*}{$\begin{array}{c}\mathrm{H}_{2} \text { storage } \\
\text { capacity } \\
(\mathrm{kg})\end{array}$} & \multirow{2}{*}{$\begin{array}{c}\text { Daily } \mathrm{H}_{2} \\
\text { demand } \\
\text { (kg/day) }\end{array}$} & \multirow{2}{*}{$\begin{array}{c}\mathrm{H}_{2} \text { produced } \\
\text { with storage } \\
\text { limit } \\
\text { (tonne/yr) }\end{array}$} & \multicolumn{2}{|c|}{$\mathrm{H}_{2}$ selling price ( $\$ / \mathrm{GJ}, \mathrm{HHV}$ basis) } \\
\hline & & & & & $\begin{array}{l}\text { With storage } \\
\text { limitation }\end{array}$ & $\begin{array}{l}\text { No storage, } \\
\text { delivered to } \\
\text { pipeline }\end{array}$ \\
\hline 2,188 & 131 & 800 & 175 & 64 & $\$ 123$ & $\$ 31.00$ \\
\hline 4,375 & 236 & 1,400 & 325 & 119 & $\$ 101$ & $\$ 26.22$ \\
\hline 8,750 & 361 & 2,300 & 550 & 201 & $\$ 79$ & $\$ 22.27$ \\
\hline
\end{tabular}

The same calculations were made using solar data from Chicago, Illinois. This is one area where a hydrogen pipeline network exists. Table 20 contains the results for this location. Because the amount of solar radiation is less than that for the other two locations, the hydrogen selling price is even greater. The hydrogen selling price is about 2.5 times the Phoenix case with the storage limitation (e.g., \$140/GJ versus $\$ 57 / \mathrm{GJ}$ for the $8,750 \mathrm{~m}^{2}$ case) and for the pipeline scenario, it is twice the hydrogen selling price compared to the Phoenix based plant (e.g., $\$ 36 / \mathrm{GJ}$ versus $\$ 18 / \mathrm{GJ}$ for the $8,750 \mathrm{~m}^{2}$ case).

Table 20: Hydrogen Production, Storage, Demand, and $\mathrm{H}_{2}$ Selling Price - Chicago

\begin{tabular}{|c|c|c|c|c|c|c|}
\hline \multirow{2}{*}{$\begin{array}{l}\text { Heliostat } \\
\text { size }\left(\mathrm{m}^{2}\right)\end{array}$} & \multirow{2}{*}{$\begin{array}{l}\mathrm{H}_{2} \text { produced } \\
\text { without } \\
\text { storage limit } \\
\text { (tonne/yr) }\end{array}$} & \multirow{2}{*}{$\begin{array}{c}\mathrm{H}_{2} \text { storage } \\
\text { capacity } \\
(\mathrm{kg})\end{array}$} & \multirow{2}{*}{$\begin{array}{l}\text { Daily } \mathrm{H}_{2} \\
\text { demand } \\
(\mathrm{kg} / \text { day })\end{array}$} & \multirow{2}{*}{$\begin{array}{c}\mathrm{H}_{2} \text { produced } \\
\text { with storage } \\
\text { limit } \\
\text { (tonne/yr) }\end{array}$} & \multicolumn{2}{|c|}{$\mathrm{H}_{2}$ selling price (\$/GJ, HHV basis) } \\
\hline & & & & & $\begin{array}{c}\text { With storage } \\
\text { limitation }\end{array}$ & $\begin{array}{l}\text { No storage, } \\
\text { delivered to } \\
\text { pipeline }\end{array}$ \\
\hline 2,188 & 83 & 800 & 100 & 36 & $\$ 221$ & $\$ 53$ \\
\hline 4,375 & 152 & 1,400 & 200 & 73 & $\$ 169$ & $\$ 45$ \\
\hline 8,750 & 246 & 2,300 & 325 & 118 & $\$ 140$ & $\$ 36$ \\
\hline
\end{tabular}

\subsection{Summary and Conclusions}

Due to the intermittent nature of the process, the solar hydrogen production system has a low capacity factor (defined as the actual hydrogen production divided by the maximum hydrogen production). There is no production at night and no production under foggy or cloudy conditions. Therefore, locating the solar plant in the desert southwest is the most attractive option. The reactor and purification equipment must be sized for peak flow rates, which are a factor of 2.5 to 3.5 greater than the average production rate. This is in comparison to a conventional fossil system, which can be sized to have a continuous production rate to meet demand. For the fueling station application, the hydrogen storage is the largest capital cost item followed by the cost of the heliostat field and compression. However, it is important to remember that a competing system (renewable or non-renewable) will also require some amount of storage as well as hydrogen compression. If the hydrogen can be consumed directly or used in another application where storage is eliminated and compression is moderate, then the hydrogen selling price from the system decreases by a factor of three. Adding a small electric heater, which supplies heat to the solar reactor when the hydrogen supply gets low, was a low-cost solution to increasing the productivity of the solar process. Using the electric heater to account for only $5 \%$ of the hydrogen production decreased the hydrogen selling price by $20 \%-25 \%$. The power production application is able to use the hydrogen directly without storage, but the cost of power from this system is more than the base electricity price of the NGCC power plant for a carbon black price less than $\$ 0.80 / \mathrm{kg}$. For the fueling station application, doubling the size of the heliostat field resulted in the lowest cost hydrogen. However, for the power production application, the smallest heliostat field was the most economic option. Additionally, for this application, because of the value of the carbon, it is more profitable to sell the carbon than burn it and produce more power. The price of the carbon black has the greatest effect on the economics for both applications. If the carbon can be sold in a specialty market for 2.3 times the price obtained in the tire industry, then the price of the hydrogen produced by the fueling station system decreases by $32 \%$. Higher value carbon markets should definitely be pursued. Although, this system uses natural gas as a feedstock, 
the net greenhouse gas emissions and overall fossil energy consumption is lower for the solar process than for the conventional fossil system. It was evident that there is a significant environmental benefit from carbon black production via the solar route than from its conventional route.

\subsection{Recommended Research}

Currently, tests are being performed to examine the compatibility of the carbon black produced from NREL's solar reactor to the different grades and types of carbon black that are currently marketed. This analysis needs to be completed in order to determine what are the applicable markets and therefore, what is the potential value of the carbon black produced from this system. Depending on the quality of the carbon black, it may also be possible to pursue new carbon black markets as they develop. Additionally, the experimental runs, to date, at the high flux solar furnace have been for high conversions of methane to hydrogen ( $>95 \%)$. This analysis has shown that for a fixed temperature, a conversion rate of $70 \%$ results in a higher net hydrogen yield. Looking at this from another perspective, a set amount of hydrogen can be obtained at a lower reactor temperature for a conversion rate of $70 \%$ versus $95 \%$. These assumptions were obtained from the reactor model and should be verified at the high flux solar furnace. 


\subsection{References}

Amos, W.A. (1998). Costs of Storing and Transporting Hydrogen. National Renewable Energy Laboratory. Golden, CO. TP-570-25106.

Chemical Marketing Reporter. (2001). Price quote of carbon black, fast extruding (N550). January.

Cooper, C.D.; Alley, F.C. (1994). Air Pollution Control A Design Approach. Prospect Heights, Illinois: Waveland Press, Inc.

Dahl, J.K.; Barocas, V.H.; Clough, D.E.; Weimer, A.W. (2002). Intrinsic kinetics for rapid decomposition of methane in an aerosol flow reactor. International Journal of Hydrogen Energy; Vol. 27, Issue 4, pp. 377-386.

EIA. (2001). Table 23. Average Price of Natural Gas Sold to Industrial Consumers by State. Energy Information Administration's Natural Gas Monthly, January 2001.

Energy Information Administration's U.S. Electric Power Industry Summary Statistics (2000).

Falcone, P. (1986). A Handbook for Solar Central Receiver Design. Sandia National Laboratories Livermore. SAND 86-8009.

Hamilton, P. (January 2002). Personal correspondence. Cabot Corporation. Riverside, California 92503.

Houghton, J.T.; Meira Filho, L.G.; Callander, B.A.; Harris, N.; Kattenberg, A.; Maskell, K., eds. (1996). Climate Change 1995. The Science of Climate Change. Published for the Intergovernmental Panel on Climate Change. New York: Cambridge University Press.

Jones, S. (December 2001). Personal correspondence. Sandia National Laboratories. Albuquerque, NM 87123.

Lane, J. M.; Spath, P. L. (2001). Technoeconomic Analysis of the Thermocatalytic Decomposition of Natural Gas. National Renewable Energy Laboratory. Golden, CO. TP-510-31351.

Lewandowski, A. (December 2001). Personal correspondence. National Renewable Energy Laboratory. Golden, CO 80401.

Renewable Resource Data Center. (December 2001). Hourly Data Files derived from the National Solar Radiation Data Base. http://rredc.nrel.gov/solar/old_data/nsrdb/hourly/

Peters, M.S.; Timmerhaus, K.D. (1991). Plant Design and Economics for Chemical Engineers. McGraw-Hill, Inc, pp. 169, 183.

Russell, D. (January 2002). Personal correspondence. Carbon black distributor. Mozel, Inc. 4003 Park Avenue, St. Louis, Missouri 63110.

Spath, P.L.; Mann, M.K. (2000a). Life Cycle Assessment of Hydrogen Production via Natural Gas Steam Reforming. National Renewable Energy Laboratory. Golden, CO. TP-570-27637. 
Spath, P.L.; Mann, M.K. (2000b). Life Cycle Assessment of a Natural Gas Combined-Cycle Power generation System. National Renewable Energy Laboratory. Golden, CO. TP-570-27715.

SRI International. (2001). Chemical Economics Handbook. Hydrogen, Menlo Park, CA. Report number 743.5000 .

SRI International. (1999). Chemical Economics Handbook. Carbon Black, Menlo Park, CA. Report number 731.3000 .

SRI International. (1994). Options for Refinery Hydrogen. Report No. 212. Menlo Park, CA.

U.S. Department of Energy. (1997). Renewable Energy Technology Characterizations. Office of Utility Technologies, Energy Efficiency and Renewable Energy. Washington, D.C. TR-109496. 


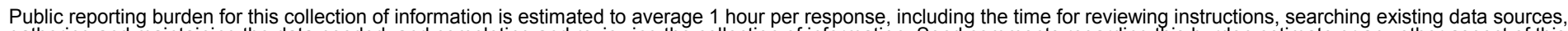


Davis Highway, Suite 1204, Arlington, VA 22202-4302, and to the Office of Management and Budget, Paperwork Reduction Project (0704-0188), Washington, DC 20503.
1. AGENCY USE ONLY (Leave blank)
2. REPORT DATE April 2002
3. REPORT TYPE AND DATES COVERED
Technical Report

4. TITLE AND SUBTITLE

Assessment of Natural Gas Splitting with a Concentrating Solar Reactor for Hydrogen Production

6. $\operatorname{AUTHOR}(\mathrm{S})$

Pamela L. Spath and Wade A. Amos

7. PERFORMING ORGANIZATION NAME(S) AND ADDRESS(ES)

8. PERFORMING ORGANIZATION REPORT NUMBER

9. SPONSORING/MONITORING AGENCY NAME(S) AND ADDRESS(ES)

National Renewable Energy Laboratory

1617 Cole Blvd.

Golden, CO 80401-3393

5. FUNDING NUMBERS

HY02.4041

11. SUPPLEMENTARY NOTES

NREL Technical Monitor:

12a. DISTRIBUTION/AVAILABILITY STATEMENT

National Technical Information Service

12b. DISTRIBUTION CODE

U.S. Department of Commerce

5285 Port Royal Road

Springfield, VA 22161

13. ABSTRACT (Maximum 200 words)

Hydrogen production via thermal decomposition of methane using a solar reactor is analyzed for two different applications: (1) for a fueling station and (2) for power production. For the fueling station, the selling price of hydrogen is controlled by the high cost of hydrogen storage and compression, combined with storage limitations of the system, which prevents maximum hydrogen production. Two alternate scenarios to lower the hydrogen production cost are evaluated: (1) sending the hydrogen directly to a pipeline network and (2) adding a small electric heater, which provides heat to the solar reactor when the hydrogen supply is low. For power production, the economics of two options for the carbon produced from the solar process are evaluated: (1) selling the carbon black and (2) burning the carbon to produce more power.

14. SUBJECT TERMS

thermal decomposition; solar reactor; hydrogen

15. NUMBER OF PAGES

16. PRICE CODE

17. SECURITY CLASSIFICATION OF REPORT Unclassified
18. SECURITY CLASSIFICATION OF THIS PAGE Unclassified
19. SECURITY CLASSIFICATION OF ABSTRACT Unclassified
20. LIMITATION OF ABSTRACT

UL 